\title{
Paleoceanography and Paleoclimatology
}

\section{RESEARCH ARTICLE \\ 10.1002/2017PA003227 \\ Key Points: \\ - First high-resolution $\varepsilon_{\mathrm{Nd}}$ records for \\ Circulation Changes in the Eastern Mediterranean Sea Over the Past 23,000 Years Inferred From Authigenic Nd Isotopic Ratios} intermediate and deep water from the EMS for the last $23 \mathrm{kyr}$

- Different circulation pattern in WMS and EMS during LGM and S1 compared to present day

- Imprint of North Atlantic climate on Mediterranean circulation and ventilation since the LGM

Supporting Information:

- Supporting Information S1

- Table S1

Correspondence to:

M. Cornuault,

marine.cornuault@gmail.com

\section{Citation:}

Cornuault, M., Tachikawa, K., Vidal, L., Guihou, A., Siani, G., Deschamps, P., et al. (2018). Circulation changes in the Eastern Mediterranean Sea over the past 23,000 years inferred from authigenic $\mathrm{Nd}$ isotopic ratios. Paleoceanography and Paleoclimatology, 33, 264-280. https:// doi.org/10.1002/2017PA003227

Received 27 JUL 2017 Accepted 29 JAN 2018 Accepted article online 14 FEB 2018 Published online 11 MAR 2018

\author{
Marine Cornuault ${ }^{1}$ (D), Kazuyo Tachikawa', Laurence Vidal' ${ }^{1}$, Abel Guihou' ${ }^{1}$ (D) Giuseppe Siani' ${ }^{2}$, \\ Pierre Deschamps $^{1}$ iD, Franck Bassinot ${ }^{3}$ iD, and Marie Revel ${ }^{4}$ \\ ${ }^{1}$ Aix-Marseille Univ, CNRS, IRD, Coll de France, Centre Européen de Recherche et d'Enseignement des Géosciences de \\ I'Environnement, Aix en Provence, France, ${ }^{2}$ GEOPS UMR 8148 CNRS, Université Paris Sud, Orsay, France, ${ }^{3}$ LSCE, UMR8212, \\ Laboratoire des Sciences du Climat et de I'Environnement/IPSL, CEA-CNRS-UVSQ and Université Paris-Saclay, Gif-Sur-Yvette, \\ France, ${ }^{4}$ Geoazur, UMR 7329, Valbonne-Sophia Antipolis, France
}

Abstract The Eastern Mediterranean Sea (EMS) is a key region to study circulation change because of its own thermohaline circulation. In this study, we focused on intermediate/deep water circulation since the Last Glacial Maximum (LGM) including the sapropel S1 period. Two cores from the Levantine Sea and the Strait of Sicily, respectively, collected at 1,780 $\mathrm{m}$ and $771 \mathrm{~m}$ water depth, were studied using ${ }^{143} \mathrm{Nd} /{ }^{144} \mathrm{Nd}\left(\varepsilon_{\mathrm{Nd}}\right)$ of foraminiferal tests and leachates as well as benthic foraminiferal stable isotopes $\left(\delta^{13} \mathrm{C}, \delta^{18} \mathrm{O}\right)$. This approach allowed the determination of variations in (1) the North Atlantic water contribution to the Mediterranean basin, (2) water exchanges at the Strait of Sicily, and (3) the influence of the Nile River over the last 23,000 years. During the LGM, high benthic foraminiferal $\delta^{13} \mathrm{C}$ values indicate well-ventilated intermediate and deep waters in the EMS. The $\varepsilon_{\mathrm{Nd}}$ values were more radiogenic than at present, reflecting a smaller contribution of unradiogenic North Atlantic waters to the EMS due to reduced exchange at the Strait of Sicily. The sluggish circulation in the EMS initiated during deglaciation was further enhanced by increased Nile River freshwater inputs between 15 ka BP and the S1 period. Partial dissolution of Nile River particles contributed to an increase in EMS $\varepsilon_{\mathrm{Nd}}$. The large $\varepsilon_{\mathrm{Nd}}$ gradient between the EMS and the Western Mediterranean Sea observed during LGM and S1 suggests that each basin had a distinct circulation mode. Decreasing $\varepsilon_{\mathrm{Nd}}$ values at the Strait of Sicily after S1 reflected improved water exchange between both basins, leading to the modern circulation pattern.

\section{Introduction}

The Mediterranean Sea thermohaline circulation is sensitive to ongoing and past climate change (Adloff et al., 2015; Rohling et al., 2015, and references therein). In the past, the sensitivity of the Eastern Mediterranean Sea (EMS) circulation has been associated to different climate backgrounds, inducing strong modifications in salinity gradients. During the Last Glacial Maximum (LGM), the lower global sea level reduced exchanges between the Atlantic and the Mediterranean (Mikolajewicz, 2011; Myers et al., 1998; Rohling \& Bryden, 1994). A regional ocean general circulation model showed that through the Strait of Gibraltar, the Mediterranean water outflow was 50\% lower than the modern value (Mikolajewicz, 2011; Myers et al., 1998). In addition, modeling studies have shown increased salinity in the EMS during the LGM (Béthoux, 1984; Myers et al., 1998). These results are consistent with the oxygen isotope records of various planktonic foraminifera indicating a strong salinity increase in the Mediterranean during the LGM (e.g., Thunell \& Williams, 1989). In response to these hydrological changes, a shift of the deep water formation zone in the EMS from the Adriatic Sea to the Northern lonian Sea is suggested from a regional ocean circulation modeling study (Mikolajewicz, 2011).

During deglaciation, a higher exchange with the Atlantic Ocean due to a rise in the global sea level preconditioned the Mediterranean Sea for the deposit of the most recent organic-rich layer sapropel S1 (10.8-6.1 cal ka BP; De Lange et al., 2008) by increasing water column stratification, which led to the progressive stagnation of intermediate and deep water circulation (Grimm et al., 2015). This result, obtained from a regional ocean circulation model coupled to a biogeochemical model, is supported by benthic foraminiferal carbon isotopic records and faunal assemblages (Cornuault et al., 2016; Grimm et al., 2015, and references therein) that highlight the leading role of slower Eastern Mediterranean thermohaline circulation in the S1 deposition. 

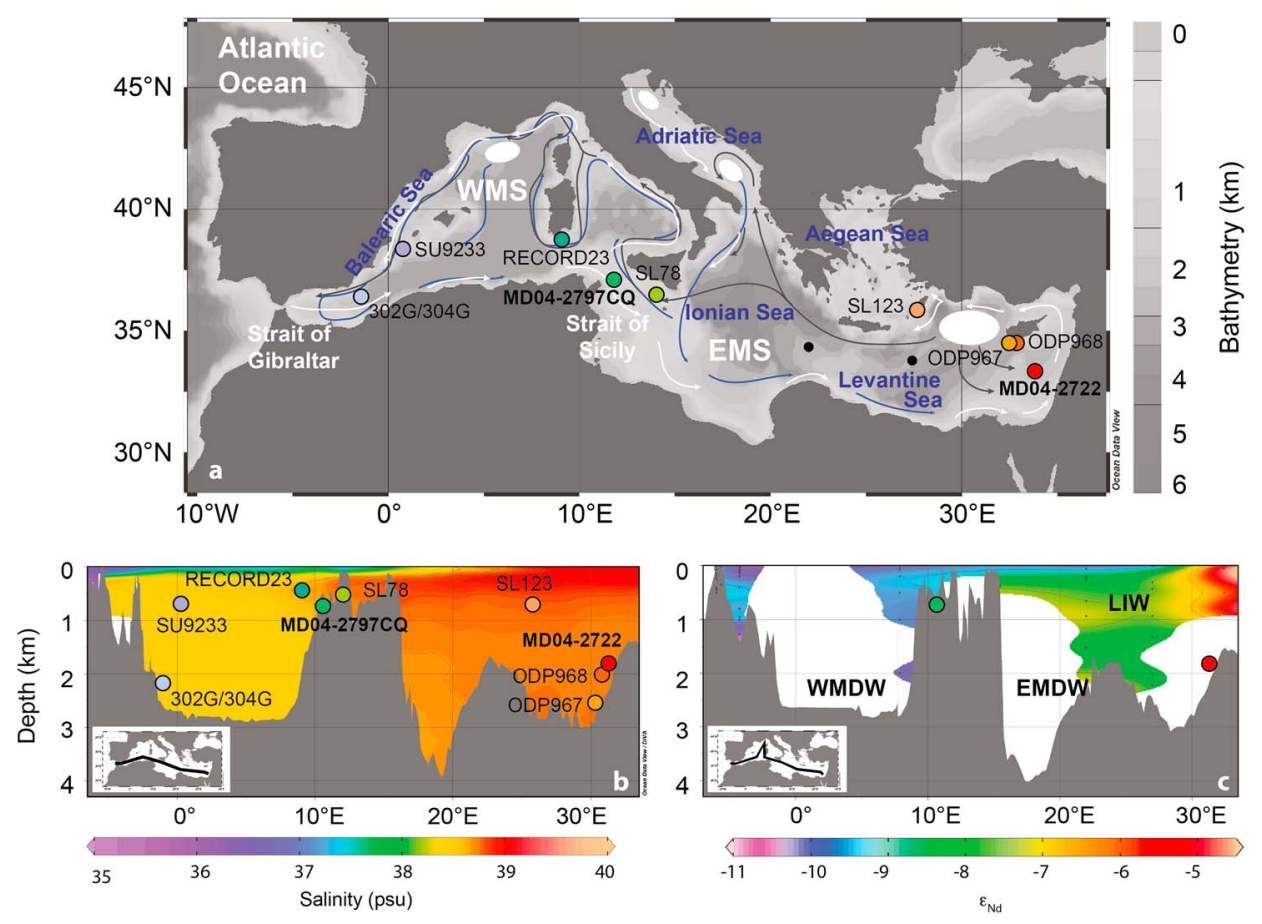

Figure 1. Core location map. (a) Bathymetric map with locations of the studied cores MD04-2722 $\left(33^{\circ} 06^{\prime} \mathrm{N}, 33^{\circ} 30^{\prime} \mathrm{E} ; 1,780 \mathrm{~m}\right.$ water depth) and MD04-2797CQ $\left(36^{\circ} 57^{\prime} \mathrm{N}, 11^{\circ} 40^{\prime} \mathrm{E} ; 771 \mathrm{~m}\right.$ water depth) and cores discussed in the text (colored dots). The modern ocean circulation pattern (modified after Millot \& Taupier-Letage, 2005) is represented by arrows: surface water circulation with white, intermediate water circulation with gray, deep water circulation with dark blue. Zones of modern intermediate and deep water mass formation are represented in white. The two black dots correspond to the seawater stations that have been used to measure the mean $\varepsilon_{\mathrm{Nd}}$ modern value of the water mass that flows at MD04-2797CQ core location. (b) The W-E present-day salinity transect. (c) The modern W-E transect of seawater eNd; interpolation is based on water column data (black dots); white areas correspond to uncharacterized zones. After Henry et al. (1994), Spivack and Wasserburg (1988), Tachikawa et al. (2004), and Vance (2002). Abbreviations: EMS = Eastern Mediterranean Sea, WMS = Western Mediterranean Sea. Figures were generated using the Ocean Data View software (Schlitzer, 2015).

Additional knowledge about Mediterranean circulation sensitivity can be gained through paleoclimate studies. Various proxies have been used to reconstruct past oceanic circulation changes. Among them, the $\delta^{13} \mathrm{C}$ signal of epibenthic foraminifera is of particular interest because it provides information about the ventilation of intermediate and deep water masses in relation to surface water convection patterns (Curry et al., 1988). This proxy has been widely used to reconstruct water mass distribution in the deep ocean (Curry \& Oppo, 2005). Today, active thermohaline circulation in the Adriatic Sea (Millot \& Taupier-Letage, 2005) and occasionally in the Aegean Sea (Roether et al., 1996) transports surface waters with high $\delta^{13} \mathrm{C}$ values of dissolved inorganic carbon to deeper water depths. It results in generally elevated $\delta^{13} \mathrm{C}$ values in the deep EMS (Pierre, 1999). The effect of surface water productivity changes on intermediate and deep water $\delta^{13} \mathrm{C}$ values is considered to be negligible due to the oligotrophic state of the Mediterranean basin (Bethoux, 1989). However, since suboxic to anoxic conditions in bottom waters of the EMS during the S1 period inhibited the development of epibenthic foraminifera, it is difficult to obtain continuous records of epibenthic $\delta^{13} \mathrm{C}$ for the S1 period.

To overcome this difficulty, the use of an independent proxy is required. Neodymium ( $\mathrm{Nd}$ ) isotopic composition is well suited to this objective. In Mediterranean water masses, seawater $\mathrm{Nd}$ isotopic composition shows a strong zonal gradient (Henry et al., 1994; Spivack \& Wasserburg, 1988; Tachikawa et al., 2004; Vance, 2004). This signal can be recorded in various sedimentary archives. However, only a few studies present temporal reconstructions of past circulation variations in the Mediterranean since the LGM based on Nd isotopic composition, and most of them concern the Western Mediterranean Sea (WMS) (Dubois-Dauphin et al., 2017; Jiménez-Espejo et al., 2015). To date, no study has presented both benthic foraminiferal $\delta^{13} \mathrm{C}$ and Nd isotopic composition for the EMS waters even though the combination has been successfully used to reconstruct bottom water circulation in the Atlantic and the Indian oceans (Piotrowski et al., 2004, 2005, 2009). 
In this study we propose to trace water mass circulation in the EMS for the last $23 \mathrm{kyr}$. We combined two complementary proxies for past ocean circulation: (1) Nd isotopic composition recorded in authigenic oxides associated with foraminiferal tests and leachates obtained from bulk sediments, and (2) benthic foraminiferal stable isotopes. The two cores studied were respectively collected in the Strait of Sicily (MD04-2797CQ: $36^{\circ} 57^{\prime} \mathrm{N}, 11^{\circ} 40^{\prime} \mathrm{E} ; 771 \mathrm{~m}$ water depth; Figure 1), which connects the western and the eastern basins of the Mediterranean Sea, and in the Levantine Sea (MD04-2722: $33^{\circ} 06^{\prime} \mathrm{N}, 33^{\circ} 30^{\prime} \mathrm{E} ; 1,780 \mathrm{~m}$ water depth; Figure 1). This study is the first attempt to reconstruct intermediate and deep water Nd isotopic composition variability in the EMS since the LGM.

\section{Oceanographic Settings}

The Mediterranean Sea is a semienclosed basin connected to the Atlantic Ocean via the Strait of Gibraltar. It possesses its own thermohaline circulation, characterized by an antiestuarine circulation (Pinardi \& Masetti, 2000; Tomczak \& Godfrey, 1994). Atlantic surface water enters the WMS through the Strait of Gibraltar (0.8-1.1 Sv; Astraldi et al., 1999; Bryden \& Kinder, 1991; Criado-Aldeanueva et al., 2012). Atlantic waters are modified (MAW, for modified Atlantic waters) by flowing into the EMS via the Strait of Sicily (Figure 1a), with a mean annual exchange rate of 1 Sv (Astraldi et al., 1999, 2001; Béranger et al., 2005). Excess evaporation during the passage from the western to the eastern basin induces a strong surface salinity gradient (Figure 1b).

Cold and dry air masses over the EMS during winter favor water mass mixing and evaporation of surface waters in the vicinity of Cyprus-Rhodes, thus promoting vertical convection (Millot \& Taupier-Letage, 2005). This results in the formation of the Levantine Intermediate water (LIW) identified by a mean temperature and salinity of $14^{\circ} \mathrm{C}$ and 38.7 , respectively (Tomczak \& Godfrey, 1994). LIW is the major intermediate water mass in the entire Mediterranean because the formation of a winter intermediate water mass in the Gulf of Lion is only ponctual (Millot, 1999) and no permanent intermediate formation site exists in the WMS (Send et al., 1999). LIW occupies between 200 and $500 \mathrm{~m}$ in water depth and flows westward across the Strait of Sicily with a mean annual exchange rate of about 1 Sv (Astraldi et al., 1999; Gasparini \& Astraldi, 2002).

The mixing of LIW with Adriatic Sea surface waters cooled by Bora winds in winter forms the Eastern Mediterranean Deep Water (EMDW) that flows below LIW (Tomczak \& Godfrey, 1994). EMDW is characterized by a mean temperature and salinity of $13^{\circ} \mathrm{C}$ and 38.6, respectively (Wüst, 1961). The Adriatic Sea has been considered as the main site of EMDW formation (Malanotte-Rizzoli \& Hecht, 1988; Pollak, 1951; Robinson et al., 1992; Wüst, 1961). However, during the 1990s, the Aegean Sea started to form unusually dense waters due to a combination of high-salinity waters intruding into the basin and strong winter cooling during 1991-1992 and 1992-1993 (Roether et al., 2014, 1996). This change in the main contributor to EMDW has become known as the Eastern Mediterranean Transient (Klein et al., 1999; Lascaratos et al., 1999; Malanotte-Rizzoli et al., 1999; Samuel et al., 1999). Today, the efficient deep water formation in EMS leads to a high dissolved oxygen content in the deep water (4-4.7 mL/L, Rohling et al., 2015). The renewal of deep water is estimated at around 100 years (Theocharis, 2009).

\section{3. $\varepsilon_{\mathrm{Nd}}$ Distribution in the Mediterranean Sea}

The Nd isotopic composition $\left({ }^{143} \mathrm{Nd} /{ }^{144} \mathrm{Nd}\right)$ is expressed as $\varepsilon_{\mathrm{Nd}}=\left[\left({ }^{143} \mathrm{Nd} /{ }^{144} \mathrm{Nd}\right)_{\text {sample }} /\left({ }^{143} \mathrm{Nd} /{ }^{144} \mathrm{Nd}\right)_{\mathrm{CHUR}}-1\right]$ $\mathrm{x} 10^{4}$, where CHUR is the CHondritic Uniform Reservoir and represents the value of the bulk Earth $\left({ }^{143} \mathrm{Nd} /{ }^{144} \mathrm{Nd}\right)_{\mathrm{CHUR}}=0.512638$; Jacobsen and Wasserburg (1980). Seawater $\varepsilon_{\mathrm{Nd}}$ values are essentially determined by the mixing of different water masses in the open ocean, whereas the interaction between dissolved and particulate fractions is significant near continental margins. In the EMS, partially dissolved Saharan dust $\left(\varepsilon_{\mathrm{Nd}}\right.$ value of around -10$)$ and Nile River particles $\left(\varepsilon_{\mathrm{Nd}}\right.$ of -3 to -1$)$ are major external Nd sources (Freydier et al., 2001; Tachikawa et al., 2004; Weldeab et al., 2002). Neodymium flux associated with Nile River water was estimated to be much smaller than inputs related to the partial dissolution of river particles (Tachikawa et al., 2004). While the contribution of Saharan dust decreases from west to east, Nile River particles that accumulate in the easternmost basin (Weldeab et al., 2002) are the main radiogenic Nd source to the EMS (Tachikawa et al., 2004). The Mediterranean margin is characterized by a large $\varepsilon_{\mathrm{Nd}}$ range from -12.5 in the SE coast of Spain, Sicily, and east coast of Italy to +5.5 in the easternmost part of the Mediterranean, southern Italy, and southern Sardinia (Ayache et al., 2016). Therefore, changes in dissolved/particulate interaction near margins may affect the $\varepsilon_{\mathrm{Nd}}$ value of different water masses and contribute to some heterogeneity in a given water mass. 
In spite of limited spatial coverage of available seawater data, Mediterranean seawater $\varepsilon_{\mathrm{Nd}}$ values present a clear zonal gradient with higher values in the EMS than in the WMS (Figure 1c). Atlantic surface water entering the WMS through the Strait of Gibraltar has unradiogenic $\varepsilon_{\text {Nd }}$ values $(-11.8 \pm 0.4$ to $-9.9 \pm 0.4$; Spivack \& Wasserburg, 1988; Tachikawa et al., 2004). $\varepsilon_{\text {Nd }}$ of MAW increases along its path through the EMS (mean value of $-8.7 \pm 1.0,1$ standard deviation (SD), $n=3$ ) in the lonian and Levantine Seas; Tachikawa et al., 2004). $\varepsilon_{\mathrm{Nd}}$ values of LIW are heterogeneous: off the mouth of the Nile in the EMS, LIW is characterized by a high mean $\varepsilon_{\mathrm{Nd}}$ value of $-5.2 \pm 0.4(1 \mathrm{SD}, n=5)$. The LIW $\varepsilon_{\mathrm{Nd}}$ value decreases during westward flow with a mean value of $-7.4 \pm 0.4$ ( $1 \mathrm{SD}, n=5$ ) in the western Levantine Sea, the Ionian Sea, and the Strait of Sicily, and $-9.8 \pm 0.5$ ( $1 \mathrm{SD}, n=3$ ) in the Alboran Sea (Tachikawa et al., 2004; Vance, 2004).

Deep waters in the Mediterranean Sea are rather homogeneous. EMDWs are characterized by $\varepsilon_{\mathrm{Nd}}$ values ranging from $-6.4 \pm 0.2$ to $-7.8 \pm 0.2$ (Tachikawa et al., 2004). $\varepsilon_{\text {Nd }}$ values of the Western Mediterranean Deep Water range from $-10.7 \pm 0.2$ to $-10.2 \pm 0.3$ (Henry et al., 1994; Spivack \& Wasserburg, 1988; Tachikawa et al., 2004).

\section{Materials and Methods}

\subsection{Core Material}

Two cores from the EMS were used in this study. The first core MD04-2722 $\left(33^{\circ} 06^{\prime} \mathrm{N}, 33^{\circ} 30^{\prime} \mathrm{E} ; 1,780 \mathrm{~m}\right.$ water depth; total core length of $36.96 \mathrm{~m}$ ) was collected south of Cyprus within the eastern Levantine Sea (Figure 1a) in 2004 during the VANIL cruise (R/V Marion Dufresne). The first $238 \mathrm{~cm}$ of sediments was investigated. The sedimentological features were previously described in Tachikawa et al. (2015). The second core MD04-2797CQ $\left(36^{\circ} 57^{\prime} \mathrm{N}, 11^{\circ} 40^{\prime} \mathrm{E} ; 771 \mathrm{~m}\right.$ water depth; total core length of $\left.10.30 \mathrm{~m}\right)$ was retrieved from the Strait of Sicily (Figure 1a) during the PRIVILEGE cruise in 2004 (R/V Marion Dufresne). We used the first $770 \mathrm{~cm}$ of the core. A lithological description of the core is available in Rouis-Zargouni et al. (2010).

At the locations of cores MD04-2722 and MD04-2797CQ, modern surface waters correspond to MAW and main bottom waters to EMDW and LIW, respectively (Figure 1).

\subsection{Analytical Methods}

4.2.1. Nd Isotope Analyses

Neodymium isotopic compositions were measured on authigenic oxide phases associated with foraminiferal tests or leachates obtained from bulk sediments. The resolution of core MD04-2722 was 4 to $10 \mathrm{~cm}$ corresponding to 0.3 to $1.3 \mathrm{kyr}$, and for core MD04-2797CQ it was 1 to $163 \mathrm{~cm}$ corresponding to 0.1 to $3.9 \mathrm{kyr}$. Additional analyses were carried out on the residual fraction of selected samples from core MD04-2797CQ (resolution of 20 to $164 \mathrm{~cm}$ corresponding to 0.6 to $3.9 \mathrm{kyr}$ ). All the sample preparation and isotopic measurements were performed at CEREGE. We prioritized analyses on foraminifera as long as the amount of material was sufficient. The sample preparation procedure was adapted from Tachikawa et al. (2014). Briefly, 20 to $30 \mathrm{mg}$ of handpicked mixed planktonic foraminiferal tests (size fraction $>150 \mu \mathrm{m}$ ) were mechanically cleaned to remove clays, and the tests were dissolved with acetic acid. Successive centrifugation steps were performed to remove residual clays. Supernatants were then dried and dissolved in $1 \mathrm{M} \mathrm{HNO}_{3}$ for $\mathrm{Nd}$ separation using ion exchange columns. The leachates were obtained from bulk sediment without a decarbonation step to minimize the detrital Nd contribution (Blaser et al., 2016; Wilson et al., 2013; Wu et al., 2015). The leaching procedure was based on the method of Wu et al. (2015). One gram of dried nondecarbonated sediment was leached with $7 \mathrm{~mL} 0.02 \mathrm{M}$ hydroxylamine hydrochloride in $25 \%(\mathrm{v} / \mathrm{v})$ acetic acid for $30 \mathrm{~min}$. Samples were then centrifuged, and the supernatant was dried and dissolved in $4 \mathrm{M} \mathrm{HCl}$ for $\mathrm{Nd}$ separation using ion exchange columns.

A two-step ion chromatography method was used to purify the $\mathrm{Nd}$ fraction. For foraminifera samples, we followed the method described in Pin and Zalduegui (1997) combining TRU-Spec columns and Ln-Spec columns. Samples were loaded using $1 \mathrm{M} \mathrm{HNO}_{3}$ on preconditioned TRU-Spec columns. Calcium, Fe, and Ba were eluted using $1 \mathrm{M} \mathrm{HNO}_{3}$ followed by $0.05 \mathrm{M} \mathrm{HNO}_{3}$. Then, the TRU-Spec columns were placed above Ln-Spec columns. The Light Rare Earth Element were eluted from the TRU-Spec columns using $0.05 \mathrm{M} \mathrm{HNO}_{3}$. After decoupling from the TRU-Spec columns, La, Ce, and Pr were removed from the $\mathrm{Ln}-\mathrm{Spec}$ columns until $\mathrm{Nd}$ was collected using $0.25 \mathrm{M} \mathrm{HCl}$. For bulk sediment samples, cationic columns containing an AG-50 W-X8 Bio-rad resin were used to separate the rare earth elements (REEs). After loading on preconditioned AG-50 W-X8 Bio-rad columns with $4 \mathrm{M} \mathrm{HCl}$, the major cations were eluted using $4 \mathrm{M} \mathrm{HCl}$ 
followed by $6 \mathrm{M} \mathrm{HNO}_{3}$. LREE were then collected using $6 \mathrm{M} \mathrm{HNO}_{3}$. The solution was successively evaporated at $90^{\circ} \mathrm{C}$, diluted with $0.25 \mathrm{M} \mathrm{HCl}$, and loaded on $\mathrm{Ln}$-Spec columns using $0.25 \mathrm{HCl}$. The undesired cations were eluted from the $\mathrm{Ln}$-Spec columns using $0.25 \mathrm{M} \mathrm{HCl}$ until $\mathrm{Nd}$ was collected. For the selected samples of core MD04-2797CQ, the residual fraction was totally dissolved with concentrated $\mathrm{HF} / \mathrm{HNO}_{3} / \mathrm{HClO}_{4}$ on a hot plate. Then the $\mathrm{Nd}$ fraction was purified as shown above. Procedural blanks were determined for each batch of sample preparation (both foraminifera and leachate samples), following the same preparation procedure and purification as samples.

Measurements of the $\mathrm{Nd}$ isotopic compositions were carried out in dry plasma mode with a Thermo Fisher Neptune ${ }^{\text {Plus }}$ Multi-Collector Inductively Coupled Plasma Mass Spectrometer equipped with an Aridus II desolvation device. Around $10 \mathrm{ng}$ to $15 \mathrm{ng}$ of $\mathrm{Nd}$ were analyzed per sample. To correct for instrumental mass bias, ${ }^{143} \mathrm{Nd} /{ }^{144} \mathrm{Nd}$ were first normalized internally to a ${ }^{146} \mathrm{Nd} /{ }^{144} \mathrm{Nd}$ of 0.7219 after correcting for any Sm interferences. Second, the samples ${ }^{143} \mathrm{Nd} /{ }^{144} \mathrm{Nd}$ were corrected by bracketing every second sample with the JNdi-1 isotopic standard solutions $\left({ }^{143} \mathrm{Nd} /{ }^{144} \mathrm{Nd}=0.512115 \pm 0.000007\right.$, Tanaka et al. (2000)). The JNdi-1 standard solutions were analyzed at the same concentrations as the samples. The reported reproducibility (2 SD) of each sample is based on self-bracketed measurements of the JNdi- 1 standard solution of each analytical session and ranged from 0.2 to $0.4 \varepsilon$ units over the course of this study. This reproducibility is comparable with the one obtained on full procedural replicate analyses of either foraminifera or leachates at selected sediment core depths. The accuracy of the correction was assessed by repeated measurements of the AMES standard solution. The mean value over the course of this study was $\varepsilon_{\mathrm{Nd}}=-13.0 \pm 0.4(2 \mathrm{SD}, n=20)$ (published value $\varepsilon_{\mathrm{Nd}}$ AMES $=-13.2 \pm 0.3$; Chauvel \& Blichert-Toft, 2001). Procedural blank values were $<100 \mathrm{pg}$ and were therefore neglected as they represented less than $1 \%$ of the $\mathrm{Nd}$ analyzed per sample.

\subsubsection{Elemental Composition of Authigenic and Detrital Fractions}

We determined the REE concentrations of some foraminiferal samples, leachates, and the residual fraction using an inductively coupled plasma mass spectrometer (Agilent 7500ce) (supporting information Figure S1). The accuracy of the instrumental measurements was determined by analyses of the Geostandards MAG-1 (marine mud) and BE-N (basalt) that were dissolved with the same digestion procedure as the residual fraction. Analytical reproducibility was less than $5 \%$, and blanks from the digestion procedure were lower than $1 \%$ of the mean measured concentration for all the analyzed elements.

\subsubsection{Stable Isotope Analyses}

Stable isotope measurements $\left(\delta^{18} \mathrm{O}\right.$ and $\left.\delta^{13} \mathrm{C}\right)$ were performed on the epibenthic species Cibicidoides pachyderma (250-315 $\mu \mathrm{m}$ size fraction) on the entire core MD04-2797CQ with a 10 to $70 \mathrm{~cm}$ resolution (corresponding to 0.1 to $1.6 \mathrm{kyr}$ ). Since this species disappeared during the sapropel interval, the resolution was decreased between 11.0 and 8.6 ka BP. Analyses were performed at LSCE using Finnigan Delta+ and Elementar Isoprime mass spectrometers. Results are expressed in per mil Vienna Pee Dee Belemnite (\%o V-PDB), with respect to the NBS19 calcite standard. The mean external reproducibility $(1 \sigma)$ of carbonate standards was $\pm 0.06 \%$ for $\delta^{18} \mathrm{O}$ and $\pm 0.04 \%$ for $\delta^{13} \mathrm{C}$.

Stable isotope measurements on core MD04-2722 were performed with a 2 to $22 \mathrm{~cm}$ resolution (corresponding to 0.1 to $1.4 \mathrm{kyr}$ ) at CEREGE and were presented in a previous study (Cornuault et al., 2016). To obtain a continuous benthic isotope record in core MD04-2722, we analyzed the epibenthic species Cibicidoides wuellerstorfi and the endobenthic species Gyroidina spp. For $\delta^{18} \mathrm{O}$ values, data from the two species were combined since the species-specific difference is small (about $0.11 \pm 0.21 \%$ o, $1 \mathrm{SD}, n=8$; Cornuault et al., 2016). In contrast, Gyroidina spp. $\delta^{13} \mathrm{C}$ data were not considered due to a significant microhabitat and possible vital effects (Cornuault et al., 2016).

\subsection{Chronology}

The upper $250 \mathrm{~cm}$ of the MD04-2722 age model was constrained by 12 radiocarbon dates of monospecific planktonic foraminifera (Tachikawa et al., 2015) (Figure 2a). Conventional radiocarbon ages were converted into calendar ages based on MARINE13 (Reimer et al., 2013) using the ${ }^{14} \mathrm{C}$ calibration software CALIB 7.0.1 (Stuiver et al., 2017). The core top and the $238 \mathrm{~cm}$ sediment samples were dated at 3.6 and $22.7 \mathrm{ka} B P$, respectively.

The age model of core MD04-2797CQ is based on 13 radiocarbon dates using INTCAL09 (Reimer et al., 2009) and the ${ }^{14} \mathrm{C}$ calibration software CALIB 6 (Stuiver et al., 1998; Stuiver \& Reimer, 1993) (Bout-Roumazeilles et al., 


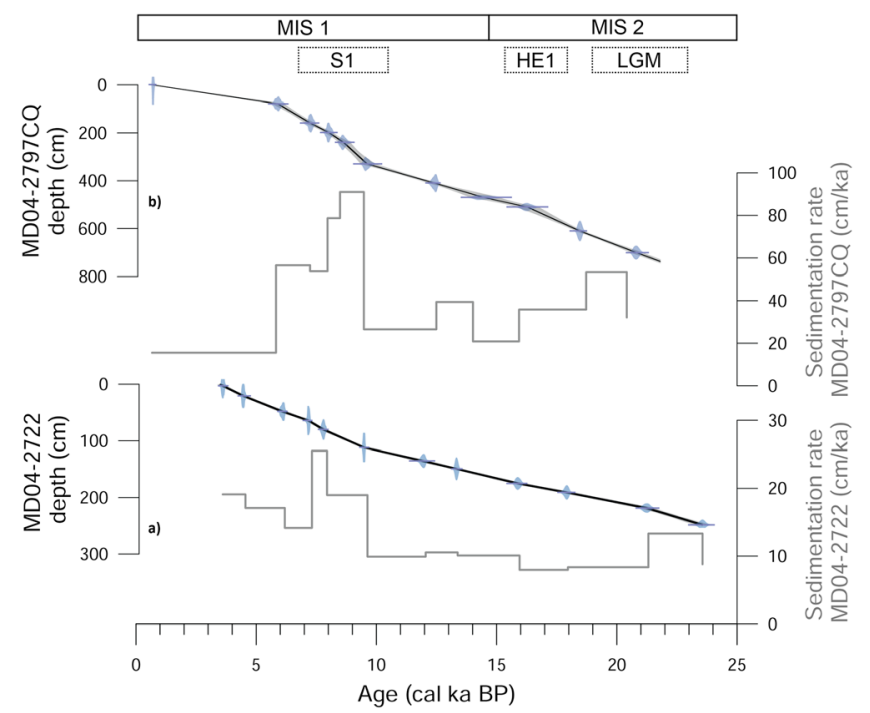

Figure 2. Age model of cores (a) MD04-2722 and (b) MD04-2797CQ. The core MD04-2797CQ chronology was built using the classical age modeling software Clam (Blaauw, 2010; version 2.2). Refer to the main text for the reservoir ages selected for each core. The age-depth model is a linear interpolation generated through 10,000 iterations. Calculations were performed at $95 \%$ confidence (gray-shaded area). The goodness of fit of 9.36 for core MD04-2722 and 6.87 for core MD04-2797CQ is satisfactory (see Blaauw, 2010, for more information on this parameter). The sedimentation rate $(\mathrm{cm} / \mathrm{ka})$ is represented in gray. The ages of LGM (23-19 ka BP), Heinrich Event 1 (HE1: 18-15.5 ka BP), and S1 (10.8-6.1 ka BP) are respectively based on Mix et al. (2001), Bard et al. (2000), and De Lange et al. (2008).
2013; Desprat et al., 2013; Sicre et al., 2013) (Figure 2b). The interval studied encompasses the last $23 \mathrm{kyr}$ (core top and $770 \mathrm{~cm}$ sediment samples respectively dated at 0.7 and 22.6 cal ka BP).

While for core MD04-2722 a 400 year reservoir age was used for the entire interval studied (Cornuault et al., 2016; Tachikawa et al., 2015), different reservoir ages were considered for core MD04-2797CQ: 400 years for the Holocene, the Younger Dryas, and the LGM, 560 years during the Bolling-Allerod, and 800 years for the Heinrich event 1 and the Older Dryas (Bout-Roumazeilles et al., 2013; Desprat et al., 2013; Sicre et al., 2013). Different reservoir ages and calibrations have only a limited impact on the final age model (less than 400 years, mean difference of about 90 years) as shown by the good consistency between the benthic foraminiferal $\delta^{18} \mathrm{O}$ records of the two cores (Figure $3 \mathrm{~b}$ ). Moreover, our interpretations focus on time intervals lasting several thousands of years such as LGM and S1. In order to estimate age uncertainty, the final age model of each core was established using the age modeling software Clam (Blaauw, 2010; version 2.2) and reported with 95\% confidence intervals (Figure 2). The age models used are consistent with the U/Th-dated coral occurrence/disappearance (Fink et al., 2015; McCulloch et al., 2010) that is concordant with our interpretations (sections 6).

\section{Results}

\section{1. $\varepsilon_{\mathrm{Nd}}$ in Foraminifera and Bulk Sediment Leachates}

$\mathrm{Nd}$ isotopic ratios were measured on both foraminiferal tests (closed circles in Figure 3a) and leachates obtained from nondecarbonated sediments (open squares in Figure $3 a$ ). We first compare these $\varepsilon_{\mathrm{Nd}}$ values obtained from the two types of archives for five depth intervals of core MD04-2722 (supporting information Table S2). Differences were less than the analytical error for each depth interval, highlighting the good consistency between the two archives (supporting information Table S2). The same approach could not be applied to core MD04-2797CQ due to the lack of foraminifera in sufficient amount to conduct measurements.

For the whole study period, the Nd isotopic signature ranged between -7 and -3 for core MD04-2797CQ and from -5 to -3 for core MD04-2722 (Figure 3a, Tables S1 and S2). The mean $\varepsilon_{\mathrm{Nd}}$ value of the three most recent samples of MD04-2797CQ was $-6.1 \pm 0.3$ (1 SD). Since no seawater $\varepsilon_{\mathrm{Nd}}$ data are available at MD042797CQ site, we estimated the modern LIW $\varepsilon_{\text {Nd }}$ value from two pieces of data in the Levantine and lonian Seas between 656 and $931 \mathrm{~m}$ (Tachikawa et al., 2004), characterized by similar salinities to that of the bottom water at the location of core MD04-2797CQ (Figure 1). The seawater value is $-7.0 \pm 0.2$, which is lower than the mean $\varepsilon_{\text {Nd }}$ value of $-6.1 \pm 0.3$ ( $1 \mathrm{SD}$ ) obtained from three most recent samples of MD04-2797CQ. We however consider that the two values are comparable, taking into account $\varepsilon_{\text {Nd }}$ heterogeneity within the LIW $(-7.4 \pm 0.4$ to $-5.2 \pm 0.4$ in Figure 1c. See also section 3). The MD04-2722 core top (3.6 ka BP) presents a value $\left(\varepsilon_{\mathrm{Nd}}=-4.4 \pm 0.2\right)$ very close to the surrounding Ocean Drilling Program (ODP) site 967 ( $-4.4 \pm 0.6$; Scrivner et al., 2004) at $3.6 \mathrm{ka}$ BP with the age model of Emeis et al. (2000) (https://doi.pangaea.de/10.1594/ PANGAEA.433068?format=html\#download). These values are more radiogenic than the modern EMDW value at 2,075 $\mathrm{m}$ in the Levantine Sea $\left(\varepsilon_{\mathrm{Nd}}=-6.4 \pm 0.2\right.$; Tachikawa et al., 2004). We are aware that the past circulation mode and preformed seawater $\mathrm{Nd}$ isotopic signatures could have varied during the last $23 \mathrm{kyr}$. However, for simplicity's sake we use the name of the modern Mediterranean water masses to describe past Mediterranean Sea circulation.

For core MD04-2722, almost constant and radiogenic $\varepsilon_{\mathrm{Nd}}$ values of around -3.5 are observed during the LGM (Figure 3a). Then, they decreased toward $-4.6 \pm 0.3$ at $15.6 \mathrm{cal} \mathrm{ka} \mathrm{BP}$, at the end of Heinrich Event 1 (Figure 3a). $\varepsilon_{\text {Nd }}$ values increased rapidly at around $15.0 \mathrm{cal}$ ka BP and stayed at around -4 until $3.6 \mathrm{cal}$ ka BP (Figure 3a). The nine pairs of duplicate measurements realized on foraminifera show good agreement within analytical uncertainties (Figure 3a). The variability and absolute $\varepsilon_{\text {Nd }}$ values of core MD04-2722 are similar to the previously published values for the ODP site 967 site but with a higher temporal resolution (Figure 4a; Scrivner et al., 2004). 


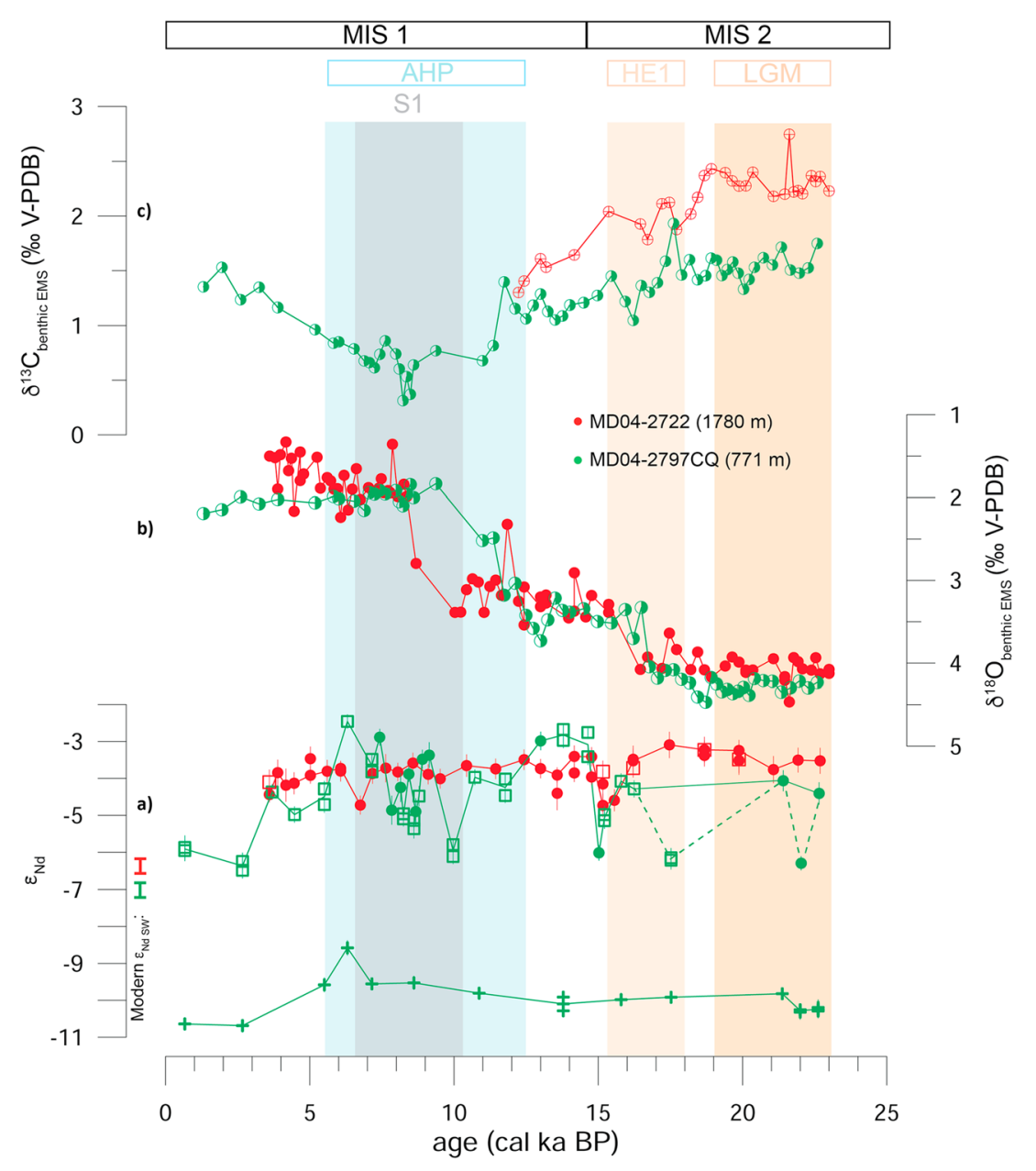

Figure 3. Nd isotope composition and foraminiferal stable isotopes records from cores MD04-2722 and MD04-2797CQ. (a) The eNd records of cores MD04-2797CQ (green) and MD04-2722 (red). Authigenic fraction was extracted from multispecies planktonic foraminifera (circles), sediment leachates (squares), and detrital fraction from residual sediments (crosses). Vertical bars represent the 2 SD error. (b) The benthic C. pachyderma $\delta{ }^{18} \mathrm{O}$ record of core MD04-2797CQ (green) and the previously published composite benthic $\delta^{18}$ O record of core MD04-2722 (red, Cornuault et al., 2016). (c) The C. pachyderma $\delta^{13} \mathrm{C}$ record of core MD04-2797CQ (green) and previously published C. wuellerstorfi $\delta^{13} \mathrm{C}$ records of core MD04-2722 (red, Cornuault et al., 2016). The different symbols represent the benthic foraminiferal species used (filled circles = composite or multispecies record, half-filled circles $=C$. pachyderma, cross-circles $=C$. wuellerstorfi).

For core MD04-2797CQ, we mainly used leachates to reconstruct seawater Nd isotopic composition. Thirteen pairs of replicate measurements of the leachates show good agreement, considering analytical uncertainties (Figure $3 \mathrm{a}$ and supporting information Table S1). For the whole study period, a greater amplitude of $\varepsilon_{\mathrm{Nd}}$ variability is observed for core MD04-2797CQ (3.6 $\varepsilon$ units) than for core MD04-2722 (1.6 $\varepsilon$ units). The core MD04$2797 \mathrm{CQ} \varepsilon_{\mathrm{Nd}}$ values around -4 marked the LGM and HE1, except for two less radiogenic values around -6 at 17.5 and $22 \mathrm{ka} \mathrm{BP}$ (Figure 3a). A decreasing trend of $\varepsilon_{\mathrm{Nd}}$ around $15 \mathrm{cal}$ ka BP and a sharp increase after the negative excursion are common features for cores MD04-2797CQ and MD04-2722 (Figure 3a). From $13.0 \mathrm{ka} B P$ to the beginning of $\mathrm{S} 1$ at $10.0 \mathrm{ka} \mathrm{BP}, \varepsilon_{\mathrm{Nd}}$ values of core MD04-2797CQ decreased from $-3.0 \pm 0.2$ to $-6.1 \pm 0.2$ (Figure 3a). During S1, higher and variable $\varepsilon_{\mathrm{Nd}}$ values ranged from -5.4 to -2.5 (especially around $8 \mathrm{cal}$ ka BP) (Figure 3a). From $6.3 \mathrm{cal} \mathrm{ka} \mathrm{BP,} \mathrm{the} \mathrm{authigenic} \mathrm{Nd}$ isotopic composition became lower, moving toward the modern value at $-6.1 \pm 0.3(n=3)$ between 2.7 and $0.7 \mathrm{ka}$ BP (Figure 3a).

$\varepsilon_{\mathrm{Nd}}$ values of the residual fraction of core MD04-2797CQ are systematically less radiogenic than the corresponding authigenic values and present less variation, with a mean value around -10 for the whole record except one higher value of -8.6 at $6.3 \mathrm{cal}$ ka BP (Figure 3a). The typical lithogenic $\varepsilon_{\text {Nd }}$ value of -10 is close to the isotopic composition of Saharan and Libyan eolian dusts (Revel et al., 2015). 


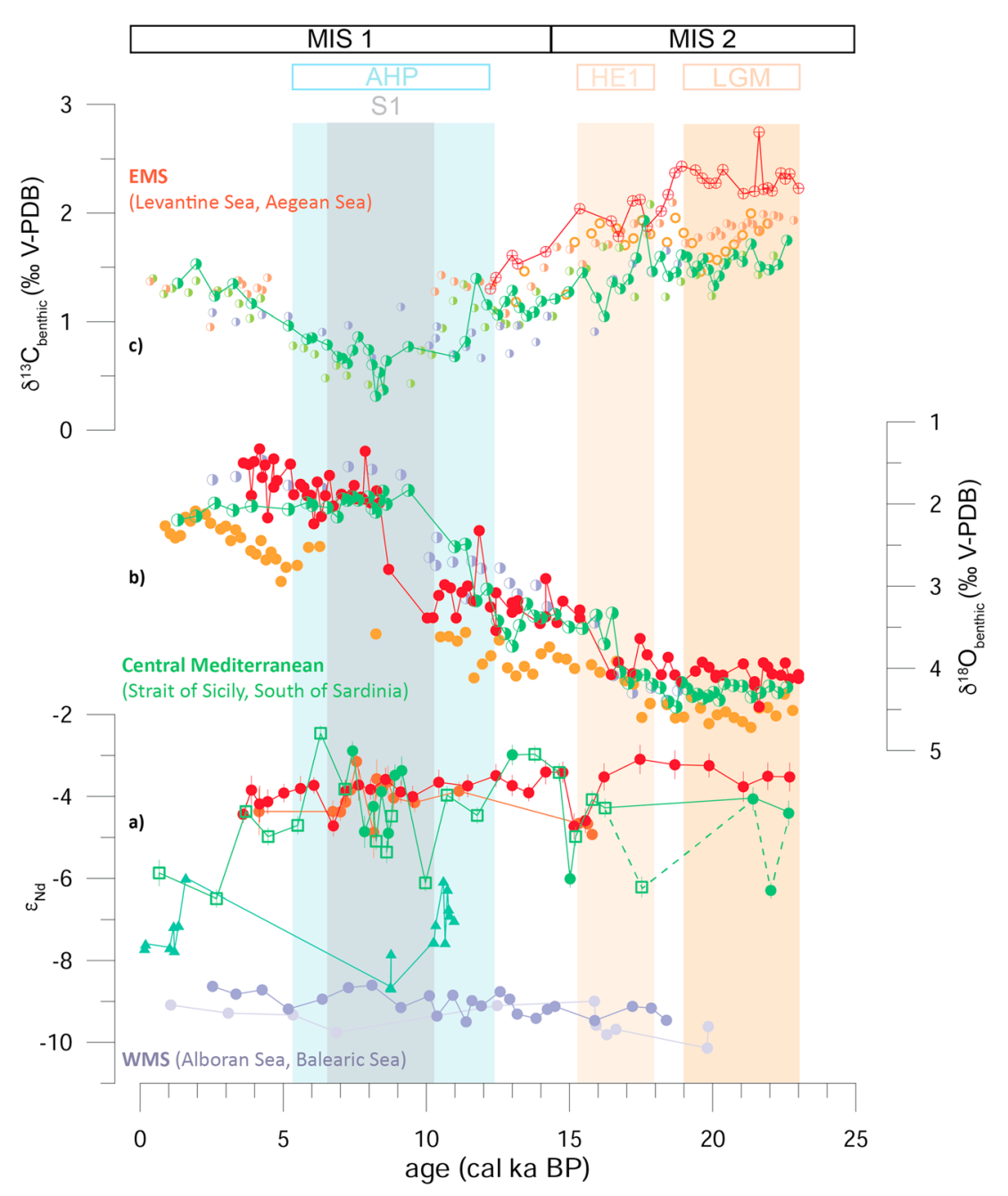

Figure 4. Circulation change in the EMS since the LGM. (a) Neodymium isotopic composition of intermediate and deep cores from the Mediterranean Sea over the last $23 \mathrm{kyr}$. The different symbols correspond to the archive type (circles: multispecies planktonic foraminifera, squares: sediment leachates, and triangles: corals). (b) The $\delta{ }^{18} \mathrm{O}$ records of the Mediterranean Sea. (c) The $\delta{ }^{13} \mathrm{C}$ record of the EMS. The different symbols correspond to the benthic foraminiferal species used (filled circles $=$ composite or multispecies record; half-filled circles $=C$. pachyderma; cross-circles $=C$. wuellerstorf; open circles $=$ C. kullenbergi). Cores are colored according to their longitude (EMS: reddish colors; ODP967 $=2550 \mathrm{~m}$, Scrivner et al., 2004; SL123 $=728$ m, Kuhnt et al., 2008; ODP968 $=1961 \mathrm{~m}$, Ziegler et al., 2010; SL78 $=450 \mathrm{~m}$, Grimm et al., 2015; MD04$2722=1780 \mathrm{~m}$, Cornuault et al., 2016, this study); central Mediterranean Sea = greenish colors (RECORD23 $=441 \mathrm{~m}$, Dubois-Dauphin et al., 2017; MD04-2797CQ = $771 \mathrm{~m}$, this study); WMS = purplish colors $(302 \mathrm{G} / 304 \mathrm{G}=1,989 \mathrm{~m} / 2,382 \mathrm{~m}$, Jiménez-Espejo et al., 2015; SU92-33 = 622 m, Dubois-Dauphin et al., 2017). Refer to Figure 1 for cores location. Abbreviation: LGM = Last Glacial Maximum, HE1 = Heinrich Event 1, AHP = African Humid Period.

Post-Archean Australian Shale-normalized REE patterns of foraminiferal tests and leachates of cores MD04-2722 and MD04-2797CQ indicate middle REE enrichment that is often found for foraminiferal tests and leachates (Wilson et al., 2013; Wu et al., 2015) (supporting information Figure S1). In contrast, the residual fraction has a flat REE pattern that is typical for the detrital fraction (supporting information Figure S2).

\subsection{Benthic Foraminiferal Stable Isotopes}

The benthic $\delta^{18} \mathrm{O}$ and $\delta^{13} \mathrm{C}$ records for core MD04-2722 were already described in Cornuault et al. (2016).

For the whole study period, C. pachyderma $\delta^{18} \mathrm{O}$ values in core MD04-2797CQ show an amplitude of 2.7\%o V-PDB, with values ranging from 2.0\% V-PDB at 9.4 cal ka BP to 4.7\%o V-PDB at 18.7 cal ka BP (Figure 3b). High and stable values around $4.5 \%$ V-PDB are recorded during the LGM (Figure $3 \mathrm{~b}$ ). The $\delta^{18} \mathrm{O}$ values decreased in the middle of HE1 by $0.7 \%$, toward a mean value of $3.7 \%$ o V-PDB from 16.5 to 13.5 cal ka BP 
Table 1

Summary of the Sensitivity Tests

\begin{tabular}{lccc}
\hline Parameter & Modern state & LGM experiment & S1 experiment \\
\hline Volume EMS & $2.2 .10^{15} \mathrm{~m}^{3 \mathrm{a}}$ & Modern & Modern \\
Surface EMS & $1.6 .10^{12} \mathrm{~m}^{2 \mathrm{a}}$ & Modern & Modern \\
Dissolved Nd concentrations EMS & $33 \mathrm{pmol} / \mathrm{kg}^{\mathrm{b}}$ & Modern & Modern \\
Dissolved Nd concentration WMS & $22 \mathrm{pmol} / \mathrm{kg}^{\mathrm{b}}$ & Modern & Modern \\
Seawater $\varepsilon_{\text {Nd EMS }}$ & $-9.0^{\mathrm{b}}$ & $-4.2 \pm 1.0^{\mathrm{c}} /-3.7 \pm 0.4^{\mathrm{c}, \mathrm{d}}$ & $-4.1 \pm 0.7^{\mathrm{c}, \mathrm{e}}$ \\
Seawater $\varepsilon_{\text {Nd WMS }}$ & $-10.5^{\mathrm{b}}$ & Modern & Modern \\
Saharan dust Nd flux EMS & $4.2 .10^{6} \mathrm{~mol} / \mathrm{yr}$ & Modern & Modern \\
Nile particle Nd flux EMS & $2.7 .10^{7} \mathrm{~mol} / \mathrm{yr}, \mathrm{g}$ & Modern & $\times 2, \times 3, \times 4$ \\
Nile River water Nd flux EMS & $4.7 .10^{1} \mathrm{~mol} / \mathrm{yr}, \mathrm{g}$ & Modern & $\times 2, \times 3, \times 4$ \\
Dissolution rate Nile River sediment EMS & $2 \%$ & Modern & Modern \\
Dissolution rate Saharan dust EMS & $2 \%$ & Modern & Modern \\
\hline
\end{tabular}

Note. EMS = Eastern Mediterranean Sea; WMS = Western Mediterranean Sea; LGM = Last Glacial Maximum.

${ }^{\mathrm{a}}$ Béthoux (1980). ${ }^{\mathrm{b}}$ Tachikawa et al. (2004). ${ }^{\mathrm{c}}$ This study. ${ }^{\mathrm{d}}$ Explanations for the calculation of this mean value are given in the main manuscript (section 6.2). ${ }^{\mathrm{e}}$ Scrivner et al. (2004). 'Grimm et al. (2015). ' $\mathrm{g}$ Values correspond to pre-Aswan Dam construction flux.

(Figure 3b). After a short interval of increase of $0.5 \%$ V-PDB at 13.5 cal ka BP just before the African Humid Period (AHP, 12.5 to 5.5 cal ka BP; Adkins et al., 2006), a strong decrease of 1.9\%o V-PDB is observed until the beginning of $\mathrm{S} 1$ at $9.4 \mathrm{cal}$ ka BP (Figure $3 \mathrm{~b}$ ). Then, $\delta^{18} \mathrm{O}$ values remain low and stable around $2.2 \%$ V-PDB until 1.3 cal ka BP (Figure $3 b$ ). Benthic oxygen isotope records are generally very similar in cores MD04-2797CQ and MD04-2722 except the period 11.5-8.5 cal ka BP (Figure 3b). However, precise comparison for this interval is difficult due to the low resolution of the records.

The benthic carbon isotopic record of core MD04-2797CQ ranges from $0.3 \%$ at 8.2 cal ka BP to $1.9 \%$ at $17.6 \mathrm{cal}$ ka BP (Figure 3c). After stable values around 1.6\% V-PDB during the LGM, a decreasing $\delta^{13} \mathrm{C}$ trend is observed until the sapropel S1. The deglaciation interval is marked by a two-step reduction in the $\delta^{13} \mathrm{C}$ values (at 0.9 and $0.7 \%$ V-PDB, respectively), one recorded at the beginning of HE1 (at $17.6 \mathrm{cal} \mathrm{ka} \mathrm{BP}$ ) and the other one during the AHP at $11.7 \mathrm{cal}$ ka BP (Figure $3 \mathrm{c}$ ). The lowest values (0.3\%o V-PDB) are found during S1 (Figure $3 \mathrm{C}$ ). Carbon isotopic composition then progressively increases from the end of S1 to the present day (1.3\% V-PDB). The $\delta^{13} \mathrm{C}$ record of $C$. wuellerstorfi of core MD04-2722 shows higher values during the LGM and a similar decreasing trend toward S1 to core MD04-2797CQ but with systematically higher $\delta^{13} \mathrm{C}$ values (Figure 3c). For core MD04-2722, the absence of epibenthic species since the AHP prevents establishing a continuous $\delta^{13} \mathrm{C}$ record from the AHP to the core top (Cornuault et al., 2016). The difference in absolute benthic foraminiferal $\delta^{13} \mathrm{C}$ values between cores MD04-2797CQ and MD04-2722 could reflect an interspecific offset due to different microhabitat conditions and/or distinct vital effects (Cornuault, 2016).

\section{3. $\varepsilon_{\text {Nd EMS }}$ Modeling}

The sensitivity of seawater $\varepsilon_{\mathrm{Nd}}$ in the EMS to various $\mathrm{Nd}$ inputs to the EMS was calculated using a simple onebox model at steady state following the approach of Tachikawa et al. (2004) (Table 1). Two time periods were selected for the experiments: the LGM and S1. The Nile River flux during the LGM was assumed to be comparable with the Holocene, whereas it was multiplied by a factor of 2,3, and 4 to examine its impact on $\varepsilon_{\text {Nd EMS }}$ values for the $\mathrm{S} 1$ case (Table 1). We are aware that the dust contribution was higher than the present during the LGM (Bout-Roumazeilles et al., 2013). However, since the net dust Nd contribution is small compared to $\mathrm{Nd}$ flux related to the seawater advection and partial Nile River particle dissolution in the EMS, the presentday dust flux was applied to both of the sensitivity tests (Table 1). The contribution of freshwater from the Wadi fossil system (Libya/Tunisia) was proposed for the formation of an older sapropel S5 (Osborne et al., 2008,2010 ). It is difficult to quantitatively integrate this potential source, however, since the amount of freshwater and particles delivered to the Gulfs of Gabès and Sirthe are not well defined. To estimate the first-order variability, we consider major well-known Nd sources: an unradiogenic contribution from Atlantic water, partially dissolved Saharan dust, and a radiogenic contribution from the Nile (linked to an enhanced African monsoon). We calculated the mean seawater $\varepsilon_{\text {Nd }}$ value in the EMS for the two time periods studied based on $\varepsilon_{\mathrm{Nd}}$ data from core MD04-2797CQ (this study), MD04-2722 (this study), and the ODP site 967 (Scrivner et al., 2004). A mean value of $-4.1 \pm 0.7$ (1 SD, $n=34$ ) was obtained for S1 (Table 1). For the LGM, a mean 
value of $-4.2 \pm 1.0$ ( $1 \mathrm{SD}, n=8$ ) was calculated with all values from cores MD04-2722 and MD04-2797CQ, while the mean value was $-3.7 \pm 0.4(1 \mathrm{SD}, n=7)$ when excluding the most unradiogenic value (see section 6.2) of -6.3 at 22 cal ka BP (Figure 3a, Table 1).

\section{Discussion}

Geochemical data from cores MD04-2722 and MD04-2797CQ showed variations in $\varepsilon_{\mathrm{Nd}}$ and benthic foraminiferal $\delta^{13} \mathrm{C}$ and $\delta^{18} \mathrm{O}$ over the last 23,000 years. We carefully interpret the observed trend by combining the $\mathrm{Nd}$ isotopic signature with benthic foraminiferal stable isotope records, considering that labile/exchangeable $\mathrm{Nd}$ could affect $\varepsilon_{\mathrm{Nd}}$ values extracted from authigenic fractions (Elmore et al., 2011). Even if the reconstructed seawater $\varepsilon_{\mathrm{Nd}}$ value of $-6.1 \pm 0.3$ ( $1 \mathrm{SD}$ ) of the most recent part of MD04-2797CQ is comparable with estimated LIW value of $-7.0 \pm 0.2$, the offset is significant. We therefore focus on the $\varepsilon_{\mathrm{Nd}}$ variability larger than $1 \varepsilon$ unit, taking into account possible heterogeneity of $\mathrm{Nd}$ isotopic signal within a given water mass (see section 3). It is worth noting that the more radiogenic $\varepsilon_{\mathrm{Nd}}$ values relative to the present-day seawater of core MD04-2797CQ over the last $23 \mathrm{kyr}$ cannot be explained solely by detrital $\mathrm{Nd}$ contamination because of systematically lower $\varepsilon_{\mathrm{Nd}}$ values of the residual fraction (Figure $3 a$ ). Based on the entire $\varepsilon_{\mathrm{Nd}}$ results obtained for this study, including the excellent agreement of the $\varepsilon_{\mathrm{Nd}}$ replicates, we assume that our geochemical data set principally indicates modifications in the circulation, hydrology, and ventilation of deep and intermediate waters as well as changes in natural dissolved and particulate interaction.

In the following, we first propose possible circulation changes for the last $23 \mathrm{kyr}$ based on the whole records obtained from the two cores studied and available data from the Mediterranean Sea. Then, we focus on the LGM and the $\mathrm{S} 1$ periods characterized by the large $\varepsilon_{\mathrm{Nd}}$ changes to examine the sensitivity of seawater $\varepsilon_{\mathrm{Nd}}$ in the EMS to further discuss the proposed hypotheses.

\subsection{Circulation Changes in the EMS Inferred From Stable Isotopes and Nd Isotopes}

We suggest that the observed reconstructed seawater $\varepsilon_{\mathrm{Nd}}$ values, which are higher than the modern seawater ones (Figure 4a), are the consequence of (1) a more predominant contribution of radiogenic $\mathrm{Nd}$ sources, such as Nile River particles (Tachikawa et al., 2004), and/or (2) a change in the deep/intermediate formation zone, near margins characterized by a high $\mathrm{Nd}$ isotopic composition (see section 3 ). Different mixing proportions of water masses cannot totally account for the observed high isotopic compositions since in the present EMS, no water mass is radiogenic enough to attain the obtained $\varepsilon_{\text {Nd }}$ values in cores MD04-2722 and MD04-2797CQ. The combination of $\mathrm{Nd}$ isotopic compositions with benthic foraminiferal stable isotopes enables the different processes to be distinguished. For instance, a change in the convection zone that affects $\varepsilon_{\mathrm{Nd}}$ values via interaction between seawater and margin sediments does not necessarily influence benthic foraminiferal $\delta^{13} \mathrm{C}$ values. In contrast, variability in freshwater inputs would lead to a large-scale circulation modification with concomitant $\varepsilon_{\mathrm{Nd}}$ and $\delta^{13} \mathrm{C}$ changes.

The mean $\varepsilon_{\text {Nd }}$ value in cores MD04-2797CQ and MD04-2722 during the LGM is $-4.9 \pm 1.2(1 \mathrm{SD}, n=3)$ and $-3.5 \pm 0.2(1 \mathrm{SD}, n=5)$, respectively, which is 2 to $3 \varepsilon$ units higher than the modern seawater value (Figure 4a). Since water transport at the Strait of Sicily is essentially equal to that at the Strait of Gibraltar (Rohling \& Bryden, 1994), a reduced contribution of Atlantic waters to the WMS in relation to low sea level (Rohling et al., 2015) and North Atlantic climatic conditions (Rogerson et al., 2010) could induce a smaller water transport from the WMS to the EMS at the Strait of Sicily, leading to an increase in $\varepsilon_{\text {Nd }}$ in the EMS. Based on the observed generally high $\varepsilon_{\text {Nd }}$ values of both cores MD04-2797CQ and MD04-2722, we hypothesize that the advection of the MAW (characterized by the lowest $\varepsilon_{\text {Nd }}$; Spivack \& Wasserburg, 1988; Tachikawa et al., 2004) to the EMS declined from the LGM to the end of HE1 due to a low glacial sea level that prevented water exchange at the Gibraltar Strait. Since the two negative $\varepsilon_{\mathrm{Nd}}$ excursions (LGM and HE1) of core MD042797CQ were observed only for the record of $\mathrm{Nd}$ isotopic composition (not for benthic foraminiferal $\delta^{18} \mathrm{O}$ and high $\delta^{13} \mathrm{C}$ records, Figure 4), it is likely that they are related to processes specific to Nd behavior (see section 6.2).

The period from LGM until HE1 was also characterized by well-ventilated intermediate and deep waters in the eastern basin as indicated by $\delta^{13} \mathrm{C}$ values higher than those of the Late Holocene (Figure 4c), which cannot be explained by general glacial/interglacial changes (Curry et al., 1988; Duplessy et al., 1988; Shackleton, 1977). 
Since elevated $\delta^{13} \mathrm{C}$ values are recorded in the WMS at the end of the LGM (Figure 4c, Dubois-Dauphin et al., 2017), they highlight active intermediate and deep water formation in both EMS and WMS.

The less radiogenic $\varepsilon_{\mathrm{Nd}}$ values in cores MD04-2797CQ and MD04-2722 occur at the end of HE1 with a decrease in the $\delta^{13} \mathrm{C}$ values during or at the end of HE1 in intermediate and deep EMS records (Figures 4a and $4 c$ ). This may suggest a higher contribution of the MAW to the EMS owing to the deglacial context that induced a rising sea level (Grant et al., 2012) and an enhanced inflow of Atlantic waters compared to glacial times (Rogerson et al., 2010). Hydrological changes are suggested by synchronous decreases in the $\delta^{18} \mathrm{O}$ planktonic record of core MD04-2797CQ (Essallami et al., 2007) and benthic records of cores MD042797CQ (Strait of Sicily), MD04-2722, and ODP site 968 (Levantine Sea) around 17 ka BP (Figure 4b). From these results, we assume that an enhanced inflow of fresher Atlantic waters, characterized by low $\varepsilon_{\mathrm{Nd}}$ and $\delta^{18} \mathrm{O}$ values, would lower the density of surface waters in the EMS leading to a reduction in convection. Benthic foraminiferal $\delta^{13} \mathrm{C}$ decreases in the Levantine Sea (ODP site 967), the Aegean Sea (SL123), and the Strait of Sicily (SL78) during or near the end of HE1 (Figure 4c) attest sluggish ventilation across the EMS, indicating the large impact of the perturbation.

$\varepsilon_{\mathrm{Nd}}$ values of cores MD04-2797CQ and MD04-2722 coincidently increase at 15 ka BP (Figure 4a). A greater contribution of water masses and/or particulate phases with higher $\varepsilon_{N d}$ values, such as the Nile River particles (Freydier et al., 2001; Frost et al., 1986; Revel et al., 2010, 2015; Weldeab et al., 2002), could explain the observed change. Initiated during or near the HE1 interval, the ventilation reduction in the EMS could be further accentuated by the fresh water from the Nile around $15 \mathrm{ka}$ BP (Revel et al., 2014) that strengthened water column stratification, as suggested by the continuous decrease in the intermediate and deep $\delta^{13} \mathrm{C}$ records from the EMS (Figure 4c).

While a constantly high $\varepsilon_{\mathrm{Nd}}$ level around -4 is recorded in core MD04-2722 from the beginning to the end of the AHP (including S1), oscillating values from -6 to -3 mark the $\varepsilon_{\mathrm{Nd}}$ signal of core MD04-2797CQ (Figure 4a). This may suggest changes in the mixing proportion of the water masses with more radiogenic waters and/or variable interaction with particulate phases (see section 6.3). Possible sporadic injections of more radiogenic Nd from Nile River particles and water can be considered, as suggested by oscillations of the Nile discharge at that time (Revel et al., 2014).

After $\mathrm{S} 1$, the decreasing $\varepsilon_{\mathrm{Nd}}$ trend of MD04-2797CQ toward the modern LIW value may indicate a greater contribution of the MAW to the EMS and less input from the Nile (Figure 4a). An improved water exchange between the WMS and the EMS at the Strait of Sicily could be responsible for a higher proportion of MAW entering the EMS, explaining the negative shift of $\varepsilon_{\mathrm{Nd}}$ values. The increase in the $\delta^{13} \mathrm{C}$ records from the EMS (core SL123, MD04-2797CQ and SL78), reflecting improved ventilation of intermediate waters, illustrates active convection in the EMS after the $\mathrm{S} 1$ perturbation (Figure 4c). These observations are consistent with the reappearance of deep-sea corals in the entire Mediterranean since the middle to late Holocene (after 5.9 ka BP) (Fink et al., 2015).

\subsection{Circulation Pattern in the Mediterranean Sea During the LGM}

The large difference of reconstructed seawater $\varepsilon_{\mathrm{Nd}}$ values between our EMS records (mean $\varepsilon_{\mathrm{Nd}}$ EMS $=$ $-4.2 \pm 1.0,1 \mathrm{SD}, n=8$ ) and existing WMS records ( $\varepsilon_{\mathrm{Nd}}$ WMS $=-9.9 \pm 0.4,1 \mathrm{SD}, n=2$; Jiménez-Espejo et al., 2015) during the LGM period (Figure 4a) could be linked to a reduced inflow of Atlantic waters to the EMS via the Strait of Sicily. This hypothesis is in line with a model simulation which showed that reduced sill depth at the Strait of Gibraltar due to a low sea level reduced water exchange to about $50 \%$ of the modern value (Mikolajewicz, 2011; Myers et al., 1998). Since water transport at the Strait of Sicily is affected by water transport at the Strait of Gibraltar, an enhanced zonal seawater $\varepsilon_{\mathrm{Nd}}$ gradient is expected during periods of reduced exchange with Atlantic waters.

A study using a regional ocean circulation model suggested that the convection zone shifted from the Adriatic to the Northern Ionian Sea during the LGM (Mikolajewicz, 2011). Considering heterogeneous but higher $\varepsilon_{\mathrm{Nd}}$ values of continental margins surrounding the Northern lonian Sea $\left(\varepsilon_{\mathrm{Nd}}=-10\right.$ to +5 ; Ayache et al., 2016) than the modern convection zone in the southern Adriatic Sea ( $\varepsilon_{\mathrm{Nd}}$ of around - 10; Ayache et al., 2016), the shift of the convection zone would induce an increase in $\varepsilon_{\mathrm{Nd}}$ values of deep/intermediate water in the EMS during the LGM (Figure 4a). Following this hypothesis, the low $\varepsilon_{\text {Nd }}$ value of -6.3 of core MD042797CQ during the LGM at $22 \mathrm{ka}$ BP could be interpreted as a short-term return to the initial convection zone. 

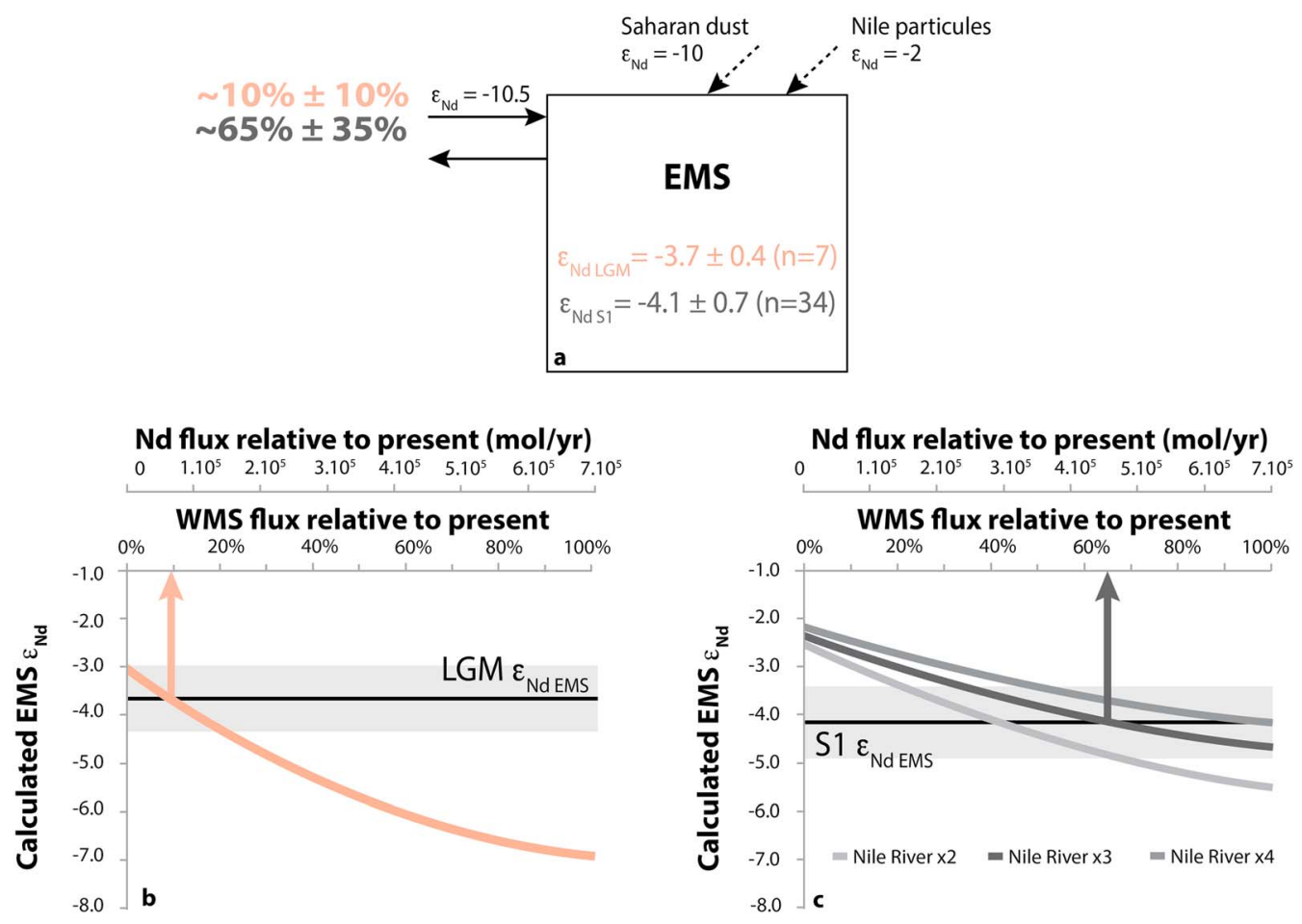

Figure 5. Sensitivity tests of $\varepsilon_{N d} E M S$ as a function of water and Nd flux from WMS and Nile contribution. The approach is following the one of Tachikawa et al. (2004). (a) Solid and dotted arrows represent water fluxes and Nd from particulate matter, respectively. Mean $\varepsilon_{\mathrm{Nd}} \mathrm{LGM}$ and $\varepsilon_{\mathrm{Nd}} \mathrm{S} 1$ values (black line) and its standard deviation (light gray-shaded area) are deduced from $\varepsilon_{\mathrm{Nd}}$ auth of cores MD04-2797CQ (this study), MD04-2722 (this study), and ODP967 (Scrivner et al., 2004) (for S1 only). (b) Sensitivity of EMS Nd isotopic ratios to Nd flux from the WMS during LGM (beige) and (c) S1 conditions (gray). Different discharges of the Nile River are tested in Figure $5 c$, the Nile River $\times 3$ is based on Grimm et al. (2015). Deduced water fluxes exchanges at the Sicily Strait during LGM and S1 are reported in Figure 5a.

We performed sensitivity tests to evaluate the impact of varying water exchange at the Strait of Sicily during the LGM (Figure $5 \mathrm{a}$ ) on the seawater $\varepsilon_{\mathrm{Nd}}$ values in the EMS. Figure $5 \mathrm{~b}$ shows the calculated LGM $\varepsilon_{\mathrm{Nd}}$ EMS as a function of $\mathrm{Nd}$ flux from the WMS relative to the present value. Assuming that dissolved $\mathrm{Nd}$ concentration in the WMS was invariable with time (section 5.3), the relative change in Nd flux could be converted into water flux changes (Figures $5 b$ and $5 c$ ). To focus on the impact of different freshwater inputs on the $\varepsilon_{N d}$ EMS for the LGM, we did not consider the negative excursion toward -6.3 at $22 \mathrm{ka}$ BP in the mean $\varepsilon_{\mathrm{Nd}}$ LGM since it could reflect a shift of the deep convection zone.

The reconstructed seawater $\varepsilon_{\text {Nd }}$ EMS value $(3.7 \pm 0.4,1 \mathrm{SD}, n=7)$ is observed when the flux from WMS is reduced to $10 \% \pm 10 \%$ of the modern value (Figure $5 \mathrm{~b}$ ). Even if decreased water exchange has already been proposed by general circulation models (Mikolajewicz, 2011; Myers et al., 1998; Rohling \& Bryden, 1994), the estimated water exchange reduction of $90 \% \pm 10 \%$ based on $\mathrm{Nd}$ isotopic composition is much more pronounced than the $50 \%$ decline resulting from more sophisticated physical models (Mikolajewicz, 2011; Myers et al., 1998). One possible reason for this difference is seawater Nd concentration variability. For instance, reduced water exchange between WMS and EMS could induce higher dissolved Nd concentration in the EMS because of the Nd contribution from the continental margin and less dilution by the MAW. This would attenuate the influence of WMS flux on $\varepsilon_{\text {Nd EMS. }}$

\subsection{Circulation Pattern in the Mediterranean Sea During the S1 Deposition}

The aforementioned hydrological modifications during deglaciation preconditioned the Mediterranean Sea for the circulation changes observed during S1 (Cornuault et al., 2016; Grimm et al., 2015). We surmise that the general ventilation decrease initiated through HE1 in the EMS (Figure 4c) was strengthened by additional freshwater inputs from the Nile, characterized by a more radiogenic $\varepsilon_{\mathrm{Nd}}$ signal. The $\varepsilon_{\mathrm{Nd}}$ higher than the modern value (Figure 4a) is in line with enhanced Nile River discharge at 15 ka BP (Revel et al., 2014). 
Scrivner et al. (2004) argued that radiogenic foraminiferal $\varepsilon_{\mathrm{Nd}}$ values during S1 in the Levantine Sea were a consequence of higher input from the Nile. In addition, the difference in reconstructed seawater $\varepsilon_{\mathrm{Nd}}$ values at intermediate and deep water depths between the EMS (mean $\varepsilon_{\mathrm{Nd}}=-4.1 \pm 0.7,1 \mathrm{SD}, n=34$; Scrivner et al., 2004; this study) and the WMS (mean $\varepsilon_{\mathrm{Nd}}=-9.0 \pm 0.4,1 \mathrm{SD}, n=7$; Dubois-Dauphin et al., 2017; JiménezEspejo et al., 2015) suggests distinct behavior of the two basins during S1 (Figure 4a). Sluggish circulation of intermediate and bottom waters at the Strait of Sicily (MD04-2797CQ and SL78) is inferred from low carbon isotope values (Figure 4c).

Using the box model, we examined the variability in EMS $\varepsilon_{\text {Nd }}$ values as a function of Nile River flux (water and particles) and variable WMS water transport (Figure 5c). A tripled Nile River flux (following the approach of Grimm et al. (2015) in their Nile experiment) associated to a reduction to $65 \% \pm 35 \%$ of the Nd flux from the WMS relative to the present value is necessary to reach the observed $\varepsilon_{\text {Nd }}$ values in the EMS for the time interval 10.8 to $6.1 \mathrm{cal}$ ka BP (Figure 5c). Without any change in the Atlantic influence to the EMS, Nile River discharge has to be multiplied by at least 4 to reach the mean $\mathrm{S} 1 \varepsilon_{\mathrm{Nd}}$ value in the EMS if the dissolved Nd concentration in the EMS and the WMS is invariable with time (Table 1 and Figure 5c).

Using a regional ocean circulation model coupled to a biogeochemical model, Grimm et al. (2015) revealed that enhanced Nile runoff and river nutrient load were not enough to create the deep water anoxic conditions necessary for the deposit of S1, highlighting the need for an additional process to reduce bottom water oxygen concentration. The slower ventilation of intermediate and deep Eastern Mediterranean waters during S1 is consistent with surface hydrological modifications resulting from a higher Nile contribution and lesser water transport at the Strait of Sicily. Unlike the LGM, the deglacial background suggests that the sill depth at Gibraltar was relatively similar to today. Thus, the reduced exchanges between the WMS and the EMS could result from a smaller zonal surface salinity gradient and decreased intermediate/deep water formation in the EMS.

This implies that the circulation during $\mathrm{S} 1$ was confined to each basin, leading to the situation that both WMS and EMS had their own circulation. For instance, reconstructed intermediate water $\varepsilon_{\mathrm{Nd}}$ values in the South of Sardinia (Dubois-Dauphin et al., 2017) are close to the values in the Alboran and Balearic Seas (DuboisDauphin et al., 2017; Jiménez-Espejo et al., 2015) during S1, whereas they matched with the values obtained for core MD04-2797CQ before and after the S1 period (Figure 4a). This spatial trend suggests a drastic decrease in the LIW flow from the EMS toward the WMS during S1 and the possible existence of WMS intermediate water for this period. The disappearance of deep corals in the EMS during the S1 period and the persistent occurrence of the organisms in the WMS indicates a weak water exchange between the two basins as early as the beginning of Holocene (Fink et al., 2015). Our results provide new evidence of the circulation mode during S1.

To sum up, circulation patterns in the Mediterranean Sea during the LGM and S1 were different from the modern one (Figure 6). While effective ventilation characterized the LGM waters (elevated $\delta^{13} \mathrm{C}$ values in the EMS, Figure 6b), a sluggish circulation marked the last sapropel (low $\delta^{13} \mathrm{C}$ values in the EMS compared to the WMS, Figure $6 \mathrm{~d}$ ). The strong zonal $\varepsilon_{\mathrm{Nd}}$ gradients (unradiogenic in the WMS versus more radiogenic in the EMS) attest a reduced water exchange between the two basins at the Strait of Sicily during the LGM and S1 period (Figures $6 a$ and $6 c$, respectively). In both cases, this indicates that WMS and EMS had their own circulation mode.

\section{Conclusions}

The combined study of the $\mathrm{Nd}$ isotopic composition of the authigenic fractions and benthic foraminiferal $\delta^{13} \mathrm{C}$ and $\delta^{18} \mathrm{O}$ from cores MD04-2797CQ and MD04-2722 collected respectively in the Strait of Sicily and the Levantine Sea, together with a one-box model, reveal circulation changes in the EMS during the last 23 kyr.

Sea level variations since the LGM, in response to climatic conditions, affected the amount of fresher water entering the Mediterranean Sea via the Strait of Gibraltar leading to changes in water exchange between the WMS and the EMS at the Strait of Sicily. During the LGM, a low sea level reduced the inflow of low salinity and unradiogenic Atlantic water to the WMS and then to the EMS. Stable and Nd isotopes suggest that the EMS circulation was characterized by active deep convection and a possible shift of the deep convection 

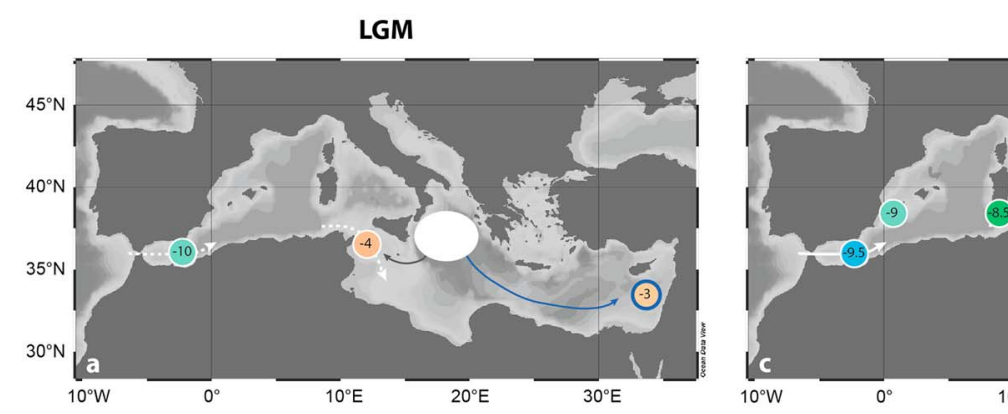

S1
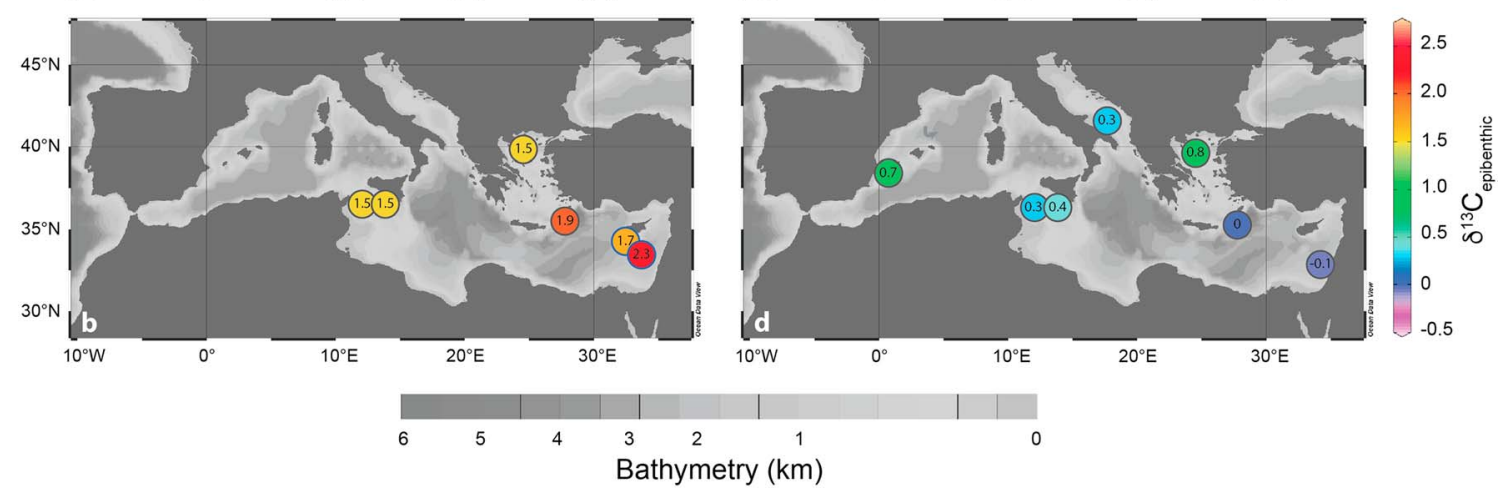

Figure 6. Conceptual pattern of circulation since 23,000 years in the Mediterranean Sea. $\varepsilon_{\mathrm{Nd}}$ and $\delta^{13} \mathrm{C}$ values are represented for (a, b) LGM and (c, d) S1. Colored dots represent $\varepsilon_{\mathrm{Nd}}$ and $\delta^{13} \mathrm{C}$ values of intermediate (white border) and deep (blue border) waters. Sites of supposed intermediate and deep water mass formation are represented in white. Full/dashed arrows represent active/reduced circulation. White arrows = surface water circulation; gray arrows = intermediate water circulation; dark blue arrows $=$ deep water circulation.

\section{Acknowledgments}

This research was funded by the ANR HAMOC (ANR-13-BS06-0003), MISTRALS/Paleomex, and the EQUIPEX ASTER-CEREGE projects. We thank Hélène Mariot and Marta Garcia for their technical support. Marie-Alexandrine Sicre and Frédérique Eynaud are thanked for providing access to the samples of core MD04-2797CQ. Data used are listed in supporting information and will be stored in the PANGEAE database (www.pangaea.de). We are deeply grateful to Mike Rogerson and another anonymous reviewer for their instructive comments that have greatly improved this manuscript. zone that is in agreement with a modeling study. During S1, enhanced discharge of low salinity and radiogenic Nile River water could have promoted strong vertical stratification of the EMS water column and sluggish intermediate/deep circulation in the eastern basin as well as accentuated the $\varepsilon_{\mathrm{Nd}}$ zonal gradient between the WMS and the EMS.

Water transport at the Strait of Gibraltar was reduced by a physical barrier due to the glacial low sea level that in turn decreased water transport at the Strait of Sicily during the LGM. A dynamical oceanic process related to a smaller zonal salinity gradient of surface water and reduced intermediate/deep water formation in the EMS diminished the water exchange between the EMS and the WMS during S1.

During LGM and S1, the circulation pattern in the Mediterranean differed from today. WMS and EMS had their own circulation mode, characterized by different ventilation states, and water exchange at the Strait of Sicily was reduced. This study provides new evidence of the great sensitivity of the Mediterranean to climate change.

\section{References}

Adkins, J., deMenocal, P., \& Eshel, G. (2006). The "African humid period" and the record of marine upwelling from excess ${ }^{230}$ Th in Ocean Drilling Program Hole 658C. Paleoceanography, 21, PA4203. https://doi.org/10.1029/2005PA001200

Adloff, F., Somot, S., Sevault, F., Jordà, G., Aznar, R., Déqué, M., et al. (2015). Mediterranean Sea response to climate change in an ensemble of twenty first century scenarios. Climate Dynamics, 45(9-10), 2775-2802. https://doi.org/10.1007/s00382-015-2507-3

Astraldi, M., Balopoulos, S., Candela, J., Font, J., Gacic, M., Gasparini, G. P., et al. (1999). The role of straits and channels in understanding the characteristics of Mediterranean circulation. Progress in Oceanography, 44(1-3), 65-108. https://doi.org/10.1016/ S0079-6611(99)00021-X

Astraldi, M., Gasparini, G. P., Gervasio, L., \& Salusti, E. (2001). Dense water dynamics along the Strait of Sicily (Mediterranean Sea). Journal of Physical Oceanography, 31(12), 3457-3475. https://doi.org/10.1175/1520-0485(2001)031\%3C3457:DWDATS\%3E2.0.CO;2

Ayache, M., Dutay, J.-C., Arsouze, T., Révillon, S., Beuvier, J., \& Jeandel, C. (2016). High resolution neodymium characterization along the Mediterranean margins and modeling of $\varepsilon_{\mathrm{Nd}}$ distribution in the Mediterranean basins. Biogeosciences Discussions, 13, 5259-5276. https:// doi.org/10.5194/bg-2016-109

Bard, E., Rostek, F., Turon, J. L., \& Gendreau, S. (2000). Hydrological impact of Heinrich events in the subtropical northeast Atlantic. Science, 289(5483), 1321-1324. https://doi.org/10.1126/science.289.5483.1321

Béranger, K., Mortier, L., \& Crépon, M. (2005). Seasonal variability of water transport through the Straits of Gibraltar, Sicily and Corsica, derived from a high-resolution model of the Mediterranean circulation. Progress in Oceanography, 66(2-4), 341-364. https://doi.org/10.1016/ j.pocean.2004.07.013 
Béthoux, J. (1980). Mean water fluxes across sections in the Mediterranean Sea, evaluated on the basis of water and salt budgets and of observed salinities. Oceanologica Acta, 3, 79-88.

Bethoux, J. (1989). Oxygen consumption, new production, vertical advection and environmental evolution in the Mediterranean Sea. Deep Sea Research Part A: Oceanographic Research Papers, 36(5), 769-781. https://doi.org/10.1016/0198-0149(89)90150-7

Béthoux, J. P. (1984). Paléo-hydrologie de la Méditerranée au cours des derniers 20000 ans. Oceanologica Acta, 7(1), 43-48.

Blaauw, M. (2010). Methods and code for "classical" age-modelling of radiocarbon sequences. Quaternary Geochronology, 5(5), 512-518. https://doi.org/10.1016/j.quageo.2010.01.002

Blaser, P., Lippold, J., Gutjahr, M., Frank, N., Link, J. M., \& Frank, M. (2016). Extracting foraminiferal seawater Nd isotope signatures from bulk deep sea sediment by chemical leaching. Chemical Geology, 439, 189-204. https://doi.org/10.1016/j.chemgeo.2016.06.024

Bout-Roumazeilles, V., Combourieu-Nebout, N., Desprat, S., Siani, G., Turon, J.-L., \& Essallami, L. (2013). Tracking atmospheric and riverine terrigenous supplies variability during the last glacial and the Holocene in central Mediterranean. Climate of the Past, 9(3), $1065-1087$. https://doi.org/10.5194/cp-9-1065-2013

Bryden, H., \& Kinder, T. (1991). Steady 2-layer exchange through the Strait of Gibraltar. Deep Sea Research Part A: Oceanographic Research Papers, 38, S445-S463. https://doi.org/10.1016/S0198-0149(12)80020-3

Chauvel, C., \& Blichert-Toft, J. (2001). A hafnium isotope and trace element perspective on melting of the depleted mantle. Earth and Planetary Science Letters, 190(3-4), 137-151. https://doi.org/10.1016/S0012-821X(01)00379-X

Cornuault M. (2016). Traçage des masses d'eau en Méditerranée orientale depuis la dernière période glaciaire: Approches géochimique (eNd, isotopes stables) et micropaléontologique (foraminifères benthiques). PhD thesis, Aix-Marseille University.

Cornuault, M., Vidal, L., Tachikawa, K., Licari, L., Rouaud, G., Sonzogni, C., \& Revel, M. (2016). Deep water circulation within the Eastern Mediterranean Sea over the last $95 \mathrm{kyr}$ : New insights from stable isotopes and benthic foraminiferal assemblages. Palaeogeography, Palaeoclimatology, Palaeoecology, 459, 1-14. https://doi.org/10.1016/j.palaeo.2016.06.038

Criado-Aldeanueva, F., Soto-Navarro, F. J., \& García-Lafuente, J. (2012). Seasonal and interannual variability of surface heat and freshwater fluxes in the Mediterranean Sea: Budgets and exchange through the Strait of Gibraltar. International Journal of Climatology, 32(2), 286-302. https://doi.org/10.1002/joc.2268

Curry, W. B., Duplessy, J. C., Labeyrie, L. D., \& Shackleton, N. J. (1988). Changes in the distribution of $\delta^{13} \mathrm{C}_{\text {of }}$ deep water $\Sigma \mathrm{CO}_{2}$ between the Last Glaciation and the Holocene. Paleoceanography, 3, 317-341. https://doi.org/10.1029/PA003i003p00317

Curry, W. B., \& Oppo, D. W. (2005). Glacial water mass geometry and the distribution of delta ${ }^{13} \mathrm{C}$ of Sigma $\mathrm{CO}_{2}$ in the western Atlantic Ocean. Paleoceanography, 20, PA1017. https://doi.org/10.1029/2004PA001021

De Lange, G. J., Thomson, J., Reitz, A., Slomp, C. P., Speranza Principato, M., Erba, E., \& Corselli, C. (2008). Synchronous basin-wide formation and redox-controlled preservation of a Mediterranean sapropel. Nature Geoscience, 1(9), 606-610. https://doi.org/10.1038/ngeo283

Desprat, S., Combourieu-Nebout, N., Essallami, L., Sicre, M. A., Dormoy, I., Peyron, O., et al. (2013). Deglacial and Holocene vegetation and climatic changes in the southern central Mediterranean from a direct land-sea correlation. Climate of the Past, 9(2), 767-787. https://doi. org/10.5194/cp-9-767-2013

Dubois-Dauphin, Q., Montagna, P., Siani, G., Douville, E., Wienberg, C., Hebbeln, D., et al. (2017). Hydrological variations of the intermediate water masses of the Western Mediterranean Sea during the past 20 ka inferred from neodymium isotopic composition in foraminifera and cold-water corals. Climate of the Past, 13(1), 17-37. https://doi.org/10.5194/cp-13-17-2017

Duplessy, J. C., Shackleton, N. J., Fairbanks, R. G., Labeyrie, L., Oppo, D., \& Kallel, N. (1988). Deepwater source variations during the last climatic cycle and their impact on the global deepwater circulation. Paleoceanography, 3, 343-360. https://doi.org/10.1029/PA003i003p00343

Elmore, A. C., Piotrowski, A. M., Wright, J. D., \& Scrivner, A. E. (2011). Testing the extraction of past seawater Nd isotopic composition from North Atlantic deep sea sediments and foraminifera. Geochemistry, Geophysics, Geosystems, 12, Q09008. https://doi.org/10.1029/2011 GC003741

Emeis, K. C., Struck, U., Schulz, H. M., Rosenberg, R., Bernasconi, S., Erlenkeuser, H., et al. (2000). Temperature and salinity variations of Mediterranean Sea surface waters over the last 16,000 years from records of planktonic stable oxygen isotopes and alkenone unsaturation ratios. Palaeogeography, Palaeoclimatology, Palaeoecology, 158(3-4), 259-280. https://doi.org/10.1016/S0031-0182(00)00053-5

Essallami, L., Sicre, M. A., Kallel, N., Labeyrie, L., \& Siani, G. (2007). Hydrological changes in the Mediterranean Sea over the last 30,000 years. Geochemistry, Geophysics, Geosystems, 8, Q07002. https://doi.org/10.1029/2007GC001587

Fink, H. G., Wienberg, C., De Pot-Holz, R., \& Hebbeln, D. (2015). Spatio-temporal distribution patterns of Mediterranean cold-water corals (Lophelia pertusa and Madrepora oculata) during the past 14,000 years. Deep Sea Research Part I: Oceanographic Research Papers, 103, 37-48. https://doi.org/10.1016/j.dsr.2015.05.006

Freydier, R., Michard, A., De Lange, G., \& Thomson, J. (2001). Nd isotopic compositions of Eastern Mediterranean sediments: Tracers of the Nile influence during sapropel S1 formation? Marine Geology, 177(1-2), 45-62. https://doi.org/10.1016/S0025-3227(01)00123-2

Frost, C., Onions, R., \& Goldstein, S. (1986). Mass balance for Nd in the Mediterranean Sea. Chemical Geology, 55(1-2), 45-50. https://doi.org/ 10.1016/0009-2541(86)90126-9

Gasparini, G. P., \& Astraldi, M. (2002). Experimental evidence of the interannual variability of currents in two Mediterranean straits: The Strait of Sicily and the Corsica Channel. CIESM, Workshop Series. Tracking-long-term hydrological change in the Mediterranean Sea, Monaco (Vol. 16, p. 134). Retrieved from http://ciesm.org/online/monographs/16/WM_16_43_46.pdf

Grant, K. M., Rohling, E. J., Bar-Matthews, M., Ayalon, A., Medina-Elizalde, M., Ramsey, C. B., et al. (2012). Rapid coupling between ice volume and polar temperature over the past 150,000 years. Nature, 491, 744-747. https://doi.org/10.1038/nature11593

Grimm, R., Maier-Reimer, E., Mikolajewicz, U., Schmiedl, G., Müller-Navarra, K., Adloff, F., et al. (2015). Late glacial initiation of Holocene Eastern Mediterranean sapropel formation. Nature Communications, 6(1). https://doi.org/10.1038/ncomms8099

Henry, F., Jeandel, C., Dupre, B., \& Minster, J.-F. (1994). Particulate and dissolved Nd in the Western Mediterranean Sea: Sources, fate and budget. Marine Chemistry, 45(4), 283-305. https://doi.org/10.1016/0304-4203(94)90075-2

Jacobsen, S. B., \& Wasserburg, G. J. (1980). Sm-Nd isotopic evolution of chondrites. Earth and Planetary Science Letters, 50(1), 139-155. https:// doi.org/10.1016/0012-821X(80)90125-9

Jiménez-Espejo, F. J., Pardos-Gené, M., Martínez-Ruiz, F., García-Alix, A., van de Flierdt, T., Toyofuku, T., et al. (2015). Geochemical evidence for intermediate water circulation in the westernmost Mediterranean over the last $20 \mathrm{kyr}$ BP and its impact on the Mediterranean Outflow. Global and Planetary Change, 135, 38-46. https://doi.org/10.1016/j.gloplacha.2015.10.001

Klein, B., Roether, W., Manca, B. B., Bregant, D., Beitzel, V., Kovacevic, V., \& Luchetta, A. (1999). The large deep water transient in the Eastern Mediterranean. Deep Sea Research Part I: Oceanographic Research Papers, 46(3), 371-414. https://doi.org/10.1016/S09670637(98)00075-2

Kuhnt, T., Schmiedl, G., Ehrmann, W., Hamann, Y., \& Andersen, N. (2008). Stable isotopic composition of Holocene benthic foraminifers from the Eastern Mediterranean Sea: Past changes in productivity and deep water oxygenation. Palaeogeography, Palaeoclimatology, Palaeoecology, 268(1-2), 106-115. 
Lascaratos, A., Roether, W., Nittis, K., \& Klein, B. (1999). Recent changes in deep water formation and spreading in the Eastern Mediterranean Sea: A review. Progress in Oceanography, 44(1-3), 5-36. https://doi.org/10.1016/S0079-6611(99)00019-1

Malanotte-Rizzoli, P., \& Hecht, A. (1988). Large-scale properties of the Eastern Mediterranean-A review. Oceanologica Acta, 11(4), 323-335.

Malanotte-Rizzoli, P., Manca, B. B., d'Alcala, M. R., Theocharis, A., Brenner, S., Budillon, G., \& Ozsoy, E. (1999). The Eastern Mediterranean in the $80 \mathrm{~s}$ and in the 90s: The big transition in the intermediate and deep circulations. Dynamics of Atmospheres and Oceans, $29(2-4), 365-395$. https://doi.org/10.1016/S0377-0265(99)00011-1

McCulloch, M., Taviani, M., Montagna, P., López Correa, M., Remia, A., \& Mortimer, G. (2010). Proliferation and demise of deep-sea corals in the Mediterranean during the Younger Dryas. Earth and Planetary Science Letters, 298(1-2), 143-152. https://doi.org/10.1016/ j.epsl.2010.07.036

Mikolajewicz, U. (2011). Modeling Mediterranean Ocean climate of the Last Glacial Maximum. Climate of the Past, 7(1), 161-180. https://doi. org/10.5194/cp-7-161-2011

Millot, C. (1999). Circulation in the Western Mediterranean Sea. Journal of Marine Systems, 20(1-4), 423-442. https://doi.org/10.1016/ S0924-7963(98)00078-5

Millot, C., \& Taupier-Letage, I. (2005). Circulation in the Mediterranean Sea. In A. Saliot (Ed.), The Mediterranean Sea (Vol. 5K, pp. 29-66). Berlin: Springer. Retrieved from http://www.springerlink.com/index/10.1007/b107143

Mix, A. C., Bard, E., \& Schneider, R. (2001). Environmental processes of the ice age: Land, oceans, glaciers (EPILOG). Quaternary Science Reviews, 20(4), 627-657.

Myers, P. G., Haines, K., \& Rohling, E. J. (1998). Modeling the paleocirculation of the Mediterranean: The Last Glacial Maximum and the Holocene with emphasis on the formation of sapropel S1. Paleoceanography, 13(6), 586-606. https://doi.org/10.1029/98PA02736

Osborne, A. H., Marino, G., Vance, D., \& Rohling, E. J. (2010). Eastern Mediterranean surface water Nd during Eemian sapropel S5: Monitoring northerly (mid-latitude) versus southerly (sub-tropical) freshwater contributions. Quaternary Science Reviews, 29(19-20), $2473-2483$. https://doi.org/10.1016/j.quascirev.2010.05.015

Osborne, A. H., Vance, D., Rohling, E. J., Barton, N., Rogerson, M., \& Fello, N. (2008). A humid corridor across the Sahara for the migration of early modern humans out of Africa 120,000 years ago. Proceedings of the National Academy of Sciences, 105(43), 16,444-16,447. https://doi. org/10.1073/pnas.0804472105

Pierre, C. (1999). The oxygen and carbon isotope distribution in the Mediterranean water masses. Marine Geology, 153(1-4), 41-55. https:// doi.org/10.1016/S0025-3227(98)00090-5

Pin, C., \& Zalduegui, J. F. S. (1997). Sequential separation of light rare-earth elements, thorium and uranium by miniaturized extraction chromatography: Application to isotopic analyses of silicate rocks. Analytica Chimica Acta, 339(1-2), 79-89. https://doi.org/10.1016/ S0003-2670(96)00499-0

Pinardi, N., \& Masetti, E. (2000). Variability of the large scale general circulation of the Mediterranean Sea from observations and modelling: A review. Palaeogeography, Palaeoclimatology, Palaeoecology, 158(3-4), 153-173. https://doi.org/10.1016/S0031-0182(00)00048-1

Piotrowski, A. M., Banakar, V. K., Scrivner, A. E., Elderfield, H., Galy, A., \& Dennis, A. (2009). Indian Ocean circulation and productivity during the last glacial cycle. Earth and Planetary Science Letters, 285(1-2), 179-189. https://doi.org/10.1016/j.epsl.2009.06.007

Piotrowski, A. M., Goldstein, S. L., Hemming, S. R., \& Fairbanks, R. G. (2004). Intensification and variability of ocean thermohaline circulation through the last deglaciation. Earth and Planetary Science Letters, 225(1-2), 205-220. https://doi.org/10.1016/j.epsl.2004.06.002

Piotrowski, A. M., Goldstein, S. L., Hemming, S. R., \& Fairbanks, R. G. (2005). Temporal relationships of carbon cycling and ocean circulation at glacial boundaries. Science, 307(5717), 1933-1938. https://doi.org/10.1126/science.1104883

Pollak, M. (1951). The sources of the deep water of the Eastern Mediterranean Sea. Journal of Marine Research, 10(1), $128-152$.

Reimer, P. J., Baillie, M. G. L., Bard, E., Bayliss, A., Beck, J. W., Blackwell, P. G., et al. (2009). IntCal09 and Marine09 radiocarbon age calibration curves, 0-50,000 years cal BP. Radiocarbon, 51(04), 1111-1150. https://doi.org/10.1017/S0033822200034202

Reimer, P. J., Bard, E., Bayliss, A., Beck, J. W., Blackwell, P. G., Ramsey, C. B., et al. (2013). Intacal13 and marine13 radiocarbon age calibration curves 0-50000 years cal BP. Radiocarbon, 55(4), 1869-1887.

Revel, M., Colin, C., Bernasconi, S., Combourieu-Nebout, N., Ducassou, E., Grousset, F. E., et al. (2014). 21,000 years of Ethiopian African monsoon variability recorded in sediments of the western Nile deep-sea fan. Regional Environmental Change, 14(5), 1685-1696. https:// doi.org/10.1007/s10113-014-0588-x

Revel, M., Ducassou, E., Grousset, F. E., Bernasconi, S. M., Migeon, S., Revillon, S., et al. (2010). 100,000 years of African monsoon variability recorded in sediments of the Nile margin. Quaternary Science Reviews, 29(11-12), 1342-1362. https://doi.org/10.1016/ j.quascirev.2010.02.006

Revel, M., Ducassou, E., Skonieczny, C., Colin, C., Bastian, L., Bosch, D., et al. (2015). 20,000 years of Nile River dynamics and environmental changes in the Nile catchment area as inferred from Nile upper continental slope sediments. Quaternary Science Reviews, 130, 200-221. https://doi.org/10.1016/j.quascirev.2015.10.030

Robinson, A. R., Malanotte-Rizzoli, P., Hecht, A., Michelato, A., Roether, W., Theocharis, A., et al. (1992). General circulation of the Eastern Mediterranean. Earth Science Reviews, 32(4), 285-309. https://doi.org/10.1016/0012-8252(92)90002-B

Roether, W., Klein, B., \& Hainbucher, D. (2014). The Eastern Mediterranean Transient. In The Mediterranean Sea (pp. 75-83). Oxford: John Wiley https://doi.org/10.1002/9781118847572.ch6

Roether, W., Manca, B. B., \& Klein, B. (1996). Recent changes in Eastern Mediterranean deep waters. Science, 271(5247), 333-335. https://doi. org/10.1126/science.271.5247.333

Rogerson, M., Colmenero-Hidalgo, E., Levine, R. C., Rohling, E. J., Voelker, A. H. L., Bigg, G. R., et al. (2010). Enhanced Mediterranean-Atlantic exchange during Atlantic freshening phases. Geochemistry, Geophysics, Geosystems, 11, Q08013. https://doi.org/10.1029/2009GC002931

Rohling, E., \& Bryden, H. (1994). Estimating past changes in the Eastern Mediterranean fresh-water budget, using reconstructions of sea-level and hydrography. Proceedings of the Koninklijke Nederlandse Akademie Van Wetenschappen-Biological Chemical Geological Physical and Medical Sciences, 97(2), 201-217.

Rohling, E., Marino, G., \& Grant, K. M. (2015). Mediterranean climate and oceanography, and the periodic development of anoxic events (sapropels). Earth-Science Reviews, 143, 62-97. https://doi.org/10.1016/j.earscirev.2015.01.008

Rouis-Zargouni, I., Turon, J.-L., Londeix, L., Essallami, L., Kallel, N., \& Sicre, M.-A. (2010). Environmental and climatic changes in the central Mediterranean Sea (Siculo-Tunisian Strait) during the last 30 ka based on dinoflagellate cyst and planktonic foraminifera assemblages Palaeogeography, Palaeoclimatology, Palaeoecology, 285(1-2), 17-29. https://doi.org/10.1016/j.palaeo.2009.10.015

Samuel, S., Haines, K., Josey, S., \& Myers, P. G. (1999). Response of the Mediterranean Sea thermohaline circulation to observed changes in the winter wind stress field in the period 1980-1993. Journal of Geophysical Research, 104, 7771-7784. https://doi.org/10.1029/ 1998JC900130 
Schlitzer, R. (2015). Ocean data view. Retrieved from http://odv.awi.de

Scrivner, A. E., Vance, D., \& Rohling, E. J. (2004). New neodymium isotope data quantify Nile involvement in Mediterranean anoxic episodes. Geology, 32(7), 565-568. https://doi.org/10.1130/G20419.1

Send, U., Font, J., Krahmann, G., Millot, C., Rhein, M., \& Tintoré, J. (1999). Recent advances in observing the physical oceanography of the Western Mediterranean Sea. Progress in Oceanography, 44(1-3), 37-64. https://doi.org/10.1016/S0079-6611(99)00020-8

Shackleton, N. J. (1977). Carbon 13 in Uvigerina: Tropical rainforest history and the equatorial Pacific carbonate dissolution cycles. Marine Science. [Retrieved from http://agris.fao.org/agris-search/search.do?recordID=US201302400843.]

Sicre, M.-A., Siani, G., Genty, D., Kallel, N., \& Essallami, L. (2013). Seemingly divergent sea surface temperature proxy records in the central Mediterranean during the last deglaciation. Climate of the Past, 9(3), 1375-1383. https://doi.org/10.5194/cp-9-1375-2013

Spivack, A., \& Wasserburg, G. (1988). Neodymium isotopic composition of the Mediterranean Outflow and the eastern North Atlantic. Geochimica et Cosmochimica Acta, 52(12), 2767-2773. https://doi.org/10.1016/0016-7037(88)90144-5

Stuiver, M., \& Reimer, P. J. (1993). Extended ${ }^{14} \mathrm{C}$ data base and revised CALIB $3.0{ }^{14} \mathrm{C}$ age calibration program. Radiocarbon, 35(01), 215-230. https://doi.org/10.1017/S0033822200013904

Stuiver, M., Reimer, P. J., Bard, E., Beck, J. W., Burr, G. S., Hughen, K. A., et al. (1998). INTCAL98 radiocarbon age calibration, 24,000-0 cal BP. Radiocarbon, 40(03), 1041-1083. https://doi.org/10.1017/S0033822200019123

Stuiver, M., Reimer, P. J., \& Reimer, R. W. (2017). CALIB 7.1 [WWW program]. Retrieved from http://calib.org, accessed 2017-11-7

Tachikawa, K., Piotrowski, A. M., \& Bayon, G. (2014). Neodymium associated with foraminiferal carbonate as a recorder of seawater isotopic signatures. Quaternary Science Reviews, 88, 1-13. https://doi.org/10.1016/j.quascirev.2013.12.027

Tachikawa, K., Roy-Barman, M., Michard, A., Thouron, D., Yeghicheyan, D., \& Jeandel, C. (2004). Neodymium isotopes in the Mediterranean Sea: Comparison between seawater and sediment signals. Geochimica et Cosmochimica Acta, 68(14), 3095-3106. https://doi.org/10.1016/ j.gca.2004.01.024

Tachikawa, K., Vidal, L., Cornuault, M., Garcia, M., Pothin, A., Sonzogni, C., et al. (2015). Eastern Mediterranean Sea circulation inferred from the conditions of S1 sapropel deposition. Climate of the Past Discussions, 10(6), 4647-4681. https://doi.org/10.5194/cpd-10-4647-2014

Tanaka, T., Togashi, S., Kamioka, H., Amakawa, H., Kagami, H., Hamamoto, T., et al. (2000). JNdi-1: A neodymium isotopic reference in consistency with LaJolla neodymium. Chemical Geology, 168(3-4), 279-281. https://doi.org/10.1016/S0009-2541(00)00198-4

Theocharis, A. (2009). Variability of the thermohaline properties in the Eastern Mediterranean during the post-EMT period (1995-2008) and SST changes in the Aegean (1985-2008). CIESM, pp. 35-40.

Thunell, R. C., \& Williams, D. F. (1989). Glacial-Holocene salinity changes in the Mediterranean Sea: Hydrographic and depositional effects. Nature, 338(6215), 493-496. https://doi.org/10.1038/338493a0

Tomczak, M., \& Godfrey, J. S. (1994). Regional oceanography: An introduction. Elsevier. Retrieved from http://books.google.com/books? $\mathrm{hl}=\mathrm{en} \& \mathrm{lr}=\& \mathrm{id}=\mathrm{ulHgBAAAQBAJ} \& \mathrm{oi}=\mathrm{fnd} \& \mathrm{pg}=\mathrm{PP} 1 \& \mathrm{dq}=\% 22 \mathrm{in}+$ response+to+comments+and+suggestions+from+colleagues+who+were +asked\%22+\%22climate+changes.+The+division+into+chapters+has+been+retained,+but+in+its\%22+\%22regions,+at+the+expense +of+the+tropics+and+subtropics+to+which+most+of+the\%22+\&ots=8DuRAkf2KS\&sig=Nwmel09t2Pzp87HTQy4mYlbHpqU

Vance, D. (2004). The use of foraminifera as a record of the past neodymium isotope composition of seawater. Paleoceanography, 19, PA2009. https://doi.org/10.1029/2003PA000957

Weldeab, S., Emeis, K. C., Hemleben, C., \& Siebel, W. (2002). Provenance of lithogenic surface sediments and pathways of riverine suspended matter in the Eastern Mediterranean Sea: Evidence from ${ }^{143} \mathrm{Nd} /{ }^{144} \mathrm{Nd}$ and ${ }^{87} \mathrm{Sr} /{ }^{86} \mathrm{Sr}$ ratios. Chemical Geology, 186(1-2), 139-149. https:// doi.org/10.1016/S0009-2541(01)00415-6

Wilson, D. J., Piotrowski, A. M., Galy, A., \& Clegg, J. A. (2013). Reactivity of neodymium carriers in deep sea sediments: Implications for boundary exchange and paleoceanography. Geochimica et Cosmochimica Acta, 109, 197-221. https://doi.org/10.1016/j.gca.2013.01.042

Wu, Q., Colin, C., Liu, Z., Thil, F., Dubois-Dauphin, Q., Frank, N., et al. (2015). Neodymium isotopic composition in foraminifera and authigenic phases of the South China Sea sediments: Implications for the hydrology of the North Pacific Ocean over the past 25 kyr. Geochemistry, Geophysics, Geosystems, 16, 3883-3904. https://doi.org/10.1002/2015GC005871

Wüst, G. (1961). On the vertical circulation of the Mediterranean Sea. Journal of Geophysical Research, 66, 3261-3271. https://doi.org/10.1029/ JZ066i010p03261

Ziegler, M., Tuenter, E., \& Lourens, L. J. (2010). The precession phase of the boreal summer monsoon as viewed from the eastern Mediterranean (ODP Site 968). Quaternary Science Reviews, 29(11-12), 1481-1490. https://doi.org/10.1016/j.quascirev.2010.03.011 